\title{
¿Large Reemergence of Anthropogenic Carbon into the Ocean's Surface Mixed Layer Sustained by the Ocean's Overturning Circulation
}

\author{
KAtsuya Toyama,,${ }^{\mathrm{a}, \mathrm{b}}$ Keith B. Rodgers, ${ }^{\mathrm{b}}$ Bruno Blanke, ${ }^{\mathrm{c}}$ DANiEle IUdicone, ${ }^{\mathrm{d}}$ MAsAo Ishit, ${ }^{\mathrm{a}}$ \\ OLIVIER AUmOnt, ${ }^{\mathrm{e}}$ AND JORGE L. SARMIENTO ${ }^{\mathrm{b}}$ \\ ${ }^{a}$ Oceanography and Geochemistry Research Department, Meteorological Research Institute, Japan Meteorological Agency, \\ Tsukuba, Ibaraki, Japan \\ ${ }^{\mathrm{b}}$ Atmospheric and Oceanic Sciences, Princeton University, Princeton, New Jersey \\ ${ }^{\mathrm{c}}$ Laboratoire d'Océanographie Physique et Spatiale, UMR 6523 CNRS-Ifremer-IRD-UBO, IUEM, Plouzané, France \\ ${ }^{\mathrm{d}}$ Department of Integrated Marine Ecology, Stazione Zoologica Anton Dohrn, Naples, Italy \\ e Sorbonne Universités, UPMC, Univ. Paris 06-CNRS-IRD-MNHN, LOCEAN/IPSL, Paris, France
}

(Manuscript received 12 October 2016, in final form 18 July 2017)

\begin{abstract}
We evaluate the output from a widely used ocean carbon cycle model to identify the subduction and obduction (reemergence) rates of anthropogenic carbon $\left(\mathrm{C}_{\mathrm{ant}}\right)$ for climatological conditions during the World Ocean Circulation Experiment (WOCE) era in 1995 using a new set of Lagrangian diagnostic tools. The principal scientific value of the Lagrangian diagnostics is in providing a new means to connect $\mathrm{C}_{\text {ant }}$ reemergence pathways to the relatively rapid renewal time scales of mode waters through the overturning circulation. Our main finding is that for this model with $2.04 \mathrm{PgC} \mathrm{yr}^{-1}$ of uptake of $\mathrm{C}_{\mathrm{ant}}$ via gas exchange, the subduction and obduction rates across the base of the mixed layer $\left(\mathrm{ML}_{\text {base }}\right)$ are 4.96 and $4.50 \mathrm{PgC} \mathrm{yr}^{-1}$, respectively, which are twice as large as the gas exchange at the surface. Given that there is net accumulation of $0.17 \mathrm{PgC} \mathrm{yr}^{-1}$ in the mixed layer itself, this implies the residual downward $\mathrm{C}_{\text {ant }}$ transport of $1.40 \mathrm{PgC} \mathrm{yr}^{-1}$ across the $\mathrm{ML}_{\text {base }}$ is associated with diffusion. Importantly, the net patterns for subduction and obduction transports of $\mathrm{C}_{\mathrm{ant}}$ mirror the large-scale patterns for transport of water volume, thereby illustrating the processes controlling $\mathrm{C}_{\text {ant }}$ uptake. Although the net transfer across the $\mathrm{ML}_{\text {base }}$ by compensating subduction and obduction is relatively smaller than the diffusion, the localized pattern of $\mathrm{C}_{\text {ant }}$ subduction and obduction implies significant regional impacts. The median time scale for reemergence of obducting particles is short $(<10 \mathrm{yr})$, indicating that reemergence should contribute to limiting future carbon uptake through its contribution to perturbing the Revelle factor for surface waters.
\end{abstract}

\section{Introduction}

The ocean is a large reservoir of anthropogenic carbon $\left(\mathrm{C}_{\mathrm{ant}}\right)$, having absorbed approximately onethird of the anthropogenic carbon emissions over the industrial period (Mikaloff-Fletcher et al. 2006; Le Quéré et al. 2010). However, Earth system models and other modeling inferences suggest that in the future a variety of factors may contribute to making the oceans less effective in absorbing carbon from the atmosphere,

Denotes content that is immediately available upon publication as open access.

Corresponding author: Katsuya Toyama, ktoyama@mri-jma.go. jp considered as a fraction of emissions (Crueger et al. 2008; Matsumoto et al. 2010). Thus, it will be important to identify and understand the processes that determine the rate at which $\mathrm{CO}_{2}$ is taken up by the ocean as well as to monitor $\mathrm{CO}_{2}$ uptake for the modern era.

The exchange of $\mathrm{C}_{\mathrm{ant}}$ between the atmosphere and ocean interior is a two-step process. The first is associated with gas exchange across the air-sea interface, and the second is associated with the exchange of $\mathrm{C}_{\mathrm{ant}}$ across the base of the ocean's mixed layer $\left(\mathrm{ML}_{\text {base }}\right)$, including upward (reemergence) and downward transport of $\mathrm{C}_{\mathrm{ant}}$ associated with obduction and subduction processes. The primary focus to date with the monitoring of ocean carbon uptake has been on the first of these, namely, using measurements of surface ocean $\mathrm{pCO}_{2}$ to infer uptake at the sea surface by gas exchange. However, it has long been thought that the principal impedance to 
carbon uptake by the ocean is rather imposed at the $\mathrm{ML}_{\text {base }}$ by ventilation processes (Bolin and Eriksson 1958; Broecker 1963; Oeschger et al. 1975; Sarmiento et al. 1992). It is only recently that efforts have emerged seeking to understand and quantify such exchanges across the $\mathrm{ML}_{\text {base }}$ (Iudicone et al. 2011; Sallée et al. 2012; Lévy et al. 2013; Bopp et al. 2015). In this paper, we will devote particular attention to the reemergence of $\mathrm{C}_{\mathrm{ant}}$, which could be important for both perturbing the carbonate buffering capacity of seawater (Revelle and Suess 1957) and impacting the pathways by which surface waters acidify under future climate change.

To identify whether reemergence is effective, it is important to consider whether the water masses rapidly reemerge after subduction relative to the time scale of the anthropogenic transient. Here, one might distinguish between the shallow overturning structures (subtropical cells) spanning approximately $45^{\circ} \mathrm{S}-45^{\circ} \mathrm{N}$ with renewal time scales of years to decades, with the obduction characteristic of the Circumpolar Deep Waters in the Southern Ocean, where the renewal time scale is significantly longer. As quantified in Suga et al. (2008) and Kwon and Riser (2004), renewal time scales for thermocline waters can be defined as the ratio of the volume of a density layer to the subduction rate for that density layer. For the case of the North Pacific Subtropical Gyre, Suga et al. (2008) identified residence times of slightly less than $10 \mathrm{yr}$ for lighter subtropical mode waters (STMW) and on the order of $20 \mathrm{yr}$ for the densest mode waters (central mode water). These renewal time scales are largely consistent with the larger-scale 5-20-yr ventilation ages for Pacific thermocline waters seen in Figs. 4a and 4b of Fine et al. (2001). For the North Atlantic, Kwon and Riser (2004) found renewal times for Eighteen Degree Water of 3-4 yr. Thus, in addition to identifying patterns of reemergence, analogous to the analysis of Bopp et al. (2015), our goal here is to evaluate the time scales over which this reemergence is expected to occur.

One of the objectives of this study is to develop and apply a new method to explicitly quantify $\mathrm{C}_{\text {ant }}$ reemergence over the global ocean. We invoke the more classical approach to quantifying subduction and obduction in order to focus on the exchange between the mixed layer (ML) and the permanent pycnocline. To this end, we have chosen to adapt and apply to $\mathrm{C}_{\mathrm{ant}}$ the Lagrangian diagnostics of subduction and obduction of Blanke et al. (2002), which was subsequently presented by Iudicone et al. (2011) and Thomas et al. (2015). Our focus is on the World Ocean Circulation Experiment (WOCE) era, in particular the year 1995 when a variety of methods indicate that the rate of net global uptake of $\mathrm{C}_{\mathrm{ant}}$ by the ocean was about $2 \mathrm{PgC} \mathrm{yr}^{-1}$ (e.g., Gruber et al. 2009; Takahashi et al.2009). Our goal is to quantify the net subduction and obduction fluxes of $\mathrm{C}_{\mathrm{ant}}$ across the $\mathrm{ML}_{\text {base }}$ and the renewal time scales and also to quantify and understand the large-scale dynamical controls.

It is also important to identify and understand the global subduction and obduction rates for $\mathrm{C}_{\mathrm{ant}}$ and interior ventilation pathways of $\mathrm{C}_{\mathrm{ant}}$ in a density framework, since the water mass signature of ventilation processes largely reflects advection along isopycnal surfaces and is intrinsically linked to the shallow and deep overturning circulation structures. The scientific value of considering $\mathrm{C}_{\mathrm{ant}}$ uptake and transport in a density framework has been emphasized in several studies (e.g., Levine et al. 2011; Nakano et al. 2015; Iudicone et al. 2016), where the focus was on Eulerian diagnostics. The Lagrangian diagnostics considered here lend themselves naturally to such an analysis, for the case of a view of subduction and obduction that emphasizes exchange between the surface ocean and the permanent pycnocline. Note that the Lagrangian particles diagnosed here follow the streamlines of the circulation. That is, they are not meant to follow the tracer but rather the streamtubes that transport tracers. This interpretation is closer to the concept of subduction in a kinematic framework and can provide an important complement to efforts that emphasize the spatial patterns of subduction and obduction in an Eulerian framework (Bopp et al. 2015). The advantage of the Lagrangian diagnostics is that they allow one to analyze and quantify explicitly the $\mathrm{C}_{\mathrm{ant}}$ flux, the interior ventilation pathways, and the time scales between subduction and obduction.

This study is organized as follows: The details of the model and the methods applied to diagnose subduction-obduction rates are described in section 2 . Estimates of physical volume and $\mathrm{C}_{\mathrm{ant}}$ transport across the $\mathrm{ML}_{\text {base }}$ are given in section 3. Sections 4 and 5 consist of the discussion and conclusions sections, respectively.

\section{Model description and analysis methods}

\section{ORCA2-LIM-PISCES}

We use physical state fields from the global configuration (ORCA2) of Océan Parallélisé in the Nucleus for European Modeling of the Ocean (NEMO-OPA) coupled to the Louvain-la-Neuve Sea Ice Model, version 2 (LIM2; Madec et al. 1998). The resolution of the model grid is $2^{\circ}$ in longitude, with latitudinal resolution varying 
from $0.5^{\circ}$ at the equator to a maximum of $1.9^{\circ}$ at approximately $20^{\circ} \mathrm{N}$ and $20^{\circ} \mathrm{S}$ and 31 levels in the vertical. Climatological European Remote Sensing Satellite-1 and European Remote Sensing Satellite-2 scatterometer monthly mean wind stresses were used for the tropics, and the NCEP-NCAR climatological dataset was used poleward of $50^{\circ} \mathrm{N}$ and $50^{\circ} \mathrm{S}$ to drive the model. Surface salinities were restored to climatology. Mesoscale processes are parameterized using Gent and McWilliams (1990), with this parameterization producing bolus velocities that are then added to the prognostic circulation fields to provide tracer transports. The model was spun up for $1500 \mathrm{yr}$ with climatological repeating seasonal forcing fields. The biweekly climatologically varying physical state fields from the final spinup year were used to drive offline the Pelagic Interaction Scheme for Carbon and Ecosystem Studies (PISCES) biogeochemistry model (Aumont and Bopp 2006). The carbonate chemistry follows the Ocean Carbon-Cycle Model Intercomparison Project (OCMIP) protocols. The model was spun up for $3000 \mathrm{yr}$. Two PISCES runs were conducted offline using the 14.6-day mean ocean transport fields that differ only in their atmospheric boundary condition for $\mathrm{CO}_{2}$ after 1860 . The first run simulates "contemporary" carbon for which the full atmospheric transient is used over 1861-1999. The second simulates a preindustrial (natural) carbon tracer by maintaining a pre-anthropogenic mixing ratio for atmospheric $\mathrm{CO}_{2}\left(\mathrm{pCO}_{2}=278 \mathrm{ppm}\right)$. As biology in the PISCES model is not dissolved inorganic carbon (DIC) limited, the biological pump behaves identically for both runs. Anthropogenic carbon is then defined as the difference between the contemporary and natural carbon state variables as they evolve in the model, both for carbon concentrations and for air-sea fluxes. As such, the model runs considered here are the same as those presented in Iudicone et al. (2016), where the assessment of the model and appropriate references were discussed.

\section{1) Ariane Lagrangian diAgnOSTIC TOOL}

Diagnostics of subduction and obduction of $\mathrm{C}_{\text {ant }}$ represent the local product of a volume flux (subduction and obduction rates) and local $\mathrm{C}_{\text {ant }}$ concentrations. Our scientific focus here is on subduction and obduction, where the (often dominant) interactions between the surface mixed layer and the seasonal pycnocline are excluded, facilitating a focus on interactions between the mixed layer and the permanent pycnocline (e.g., Qiu and Huang 1995). Specifically, we are interested in $C_{a n t}$ that remains at least a full year below the $\mathrm{ML}_{\text {base }}$ before reemergence to qualify for being accounted for in $\mathrm{C}_{\mathrm{ant}}$ subduction and obduction budgets. To this end we opt to use the Ariane Lagrangian tracking tool (Blanke and Grima 2011) and apply this to quantify subduction and obduction rates following the Lagrangian method of Blanke et al. (2002). The Ariane diagnostic tool has been widely applied in the oceanographic literature (Blanke and Raynaud 1997; Blanke et al. 2002). Here, we wish to emphasize two points to clarify the method and its appropriateness to the scientific questions raised by this study. First, the Lagrangian trajectories calculated by Ariane use the full three-dimensional circulation fields, including the bolus velocities for the mesoscale parameterization. Thus, the circulation fields seen by the Lagrangian trajectories are the very same transport fields comprising the circulation fields that transport properties in the forward ocean model. Second, it is important to emphasize that individual Lagrangian particles used to calculate trajectories are not intended to represent a simulation of individual carbon molecules. Carbon molecules experience explicit diffusion, and Lagrangian particles do not. Rather, the Lagrangian particles are used to characterize streamtubes of transport and to interpret the explicit simulation of $\mathrm{C}_{\mathrm{ant}}$ by the biogeochemical model. We expect that the fact that the Lagrangian diagnostics do not represent diffusion by construction can potentially be useful for many scientific applications, as this may help us to deconvolve the effects of transport by circulation fields and diffusion (and potentially biology, depending on the application).

\section{2) Subduction-Obduction diagnostics}

Subduction and obduction rates are considered through the application of the Lagrangian diagnostics presented in Blanke et al. (2002) and applied here for the case of $\mathrm{C}_{\mathrm{ant}}$. Volume transport of water across the $\mathrm{ML}_{\text {base }}$ is diagnosed offline at each model time step and at each model grid point using the equation for the instantaneous subduction rate (Cushman-Roisin 1987):

$$
S=w_{h}+\mathbf{u}_{h} \cdot \nabla_{H} h+\partial_{t} h
$$

where $w$ and $\mathbf{u}$ are vertical and horizontal velocities, respectively, and $h$ is mixed layer depth (MLD; which, in this study, is defined as the depth at which $\sigma_{0}$ differs by $0.01 \mathrm{~kg} \mathrm{~m}^{-3}$ from its surface value: $\left.\Delta \sigma_{0}=0.01\right)$. Negative values are considered as subduction, and positive values are considered as obduction. The first two terms on the right-hand side of Eq. (1) denote advective volume transport, and the third term accounts for the transport resulting from shoaling-deepening of the mixed layer (detrainment-entrainment). Hereafter, we refer to the first and the second terms of Eq. (1) as vertical and horizontal (zonal and meridional) transport terms, 
respectively, and the third term as the MLD tendency term.

The application of the Eulerian diagnostic in Eq. (1) will by itself identify instantaneous subduction and obduction rates, reflecting exchange with both the seasonal and permanent pycnocline. To achieve our scientific objectives of focusing exclusively on exchanges between the mixed layer and the permanent pycnocline, we introduce the Lagrangian filter developed and presented by Blanke et al. (2002). This is conceived within the "quantitative mode" framework of the Ariane Lagrangian tool, where the $\mathrm{ML}_{\text {base }}$ is defined to be both the initial and final surface (for starting and stopping) of particles that travel through the ocean interior. The quantitative mode of the Ariane tool specializes in giving statistics of a tremendous number of particles, instead of giving detailed trajectories of selected particles. The accuracy of the statistics will be improved as the number of particles seeded is increased. Thus, several million particles are seeded at the $\mathrm{ML}_{\text {base, }}$ with the number of particles released at each grid point over the evolving seasonal cycle being scaled by the transports identified through the application of Eq. (1). That is, each Lagrangian particle is assigned initial transport proportional to the Eulerian transport defined by Eq. (1). Any of the individual particles explains only a fraction of the total transport falling below a prescribed maximum value $\left[\mathrm{TR}_{0}\right.$; here $\mathrm{TR}_{0}=0.005 \mathrm{~Sv}(1 \mathrm{~Sv} \equiv$ $\left.\left.10^{6} \mathrm{~m}^{3} \mathrm{~s}^{-1}\right)\right]$. We remind ourselves that for both the subduction-obduction representation in Eq. (1) and the case where the Lagrangian filter is applied, we use the full three-dimensional circulation fields that include the bolus velocities. For subduction, this can be treated as a forward trajectory calculation, and for obduction, this can be treated as a reverse (i.e., backward trajectory) calculation (the signs of the velocity fields are reversed for the backward trajectory calculation). For the case of subduction (obduction) calculation, particles are released as they enter the ocean interior (the mixed layer), tracked forward (backward) in time, and then they are stopped the next (previous) time they cross the $\mathrm{ML}_{\text {base }}$. For the case of the transport terms in Eq. (1), particles are placed at the grid surfaces. For the case of the MLD tendency term in Eq. (1), particles are placed within a grid box that is above (below) MLD at a time step and below (above) MLD at the next (previous) for the forward (backward) calculation. There is a special case where a particle is released for subduction calculation just above the $\mathrm{ML}_{\mathrm{base}}$ during a time of ML shoaling (and thereby poised to have the $\mathrm{ML}_{\text {base }}$ pass by as it is displaced upward) and where the particle is not displaced spatially out of the initial grid box over the integrated seasonal cycle. In that case the particle will be re-entrained into the mixed layer before a full year transpires, as the physical state variables used here represent a repeating seasonal cycle only and will be removed by the Lagrangian filter. For each particle, the space-time coordinates, age, and water properties of the original and final $\mathrm{ML}_{\text {base }}$ crossings are recorded, facilitating a focus on those transports associated with particles that are below the $\mathrm{ML}_{\text {base }}$ for a specific period of time. To estimate the exchange between the mixed layer and the permanent pycnocline, we use 1 year as a criterion. Note that the seasonally varying $M L_{\text {base }}$ is used as both the initial and final surfaces in the quantitative-mode Ariane diagnostics, unlike simplified kinematic diagnostics of subduction in Lagrangian coordinates that use only the late-winter $\mathrm{ML}_{\text {base }}$ and calculate subduction rates as a net integration over 1 yr [Eq. (3) of Huang and Qiu 1994, see also their appendix]. That the subduction and obduction rates calculated in this study are largely based on Eulerian equation (1), while invoking a Lagrangian filter, means that the concept here is much closer to the kinematic diagnostics. One of our objectives is to explicitly compare the results obtained with and without the Lagrangian filter, to identify the relative magnitudes of subduction and obduction between the two approaches, and also to identify if they reveal distinct patterns.

Having thus characterized the subduction and obduction rates for the physical circulation, the tools are in place for the application to the case of the subduction and obduction rates for the transient $\mathrm{C}_{\mathrm{ant}}$ signal at the time of WOCE. The prognostic $\mathrm{C}_{\mathrm{ant}}$ distribution is calculated offline using the PISCES model, using the ORCA2-LIM seasonally varying circulation (including mixing) and physical state evolution. The subduction and obduction rates for $\mathrm{C}_{\mathrm{ant}}$ are calculated for the year 1995 as the product of the physical subduction and obduction rates and the local anthropogenic DIC (DIC $\left.{ }_{a n t}\right)$ concentration (i.e., $\mathrm{DIC}_{\mathrm{ant}}$ concentration at the $\mathrm{ML}_{\text {base }}$ at the time of subduction and/or obduction). The use of the $C_{a n t}$ value at the $M L_{\text {base }}$ means that an upward motion of relatively $\mathrm{C}_{\mathrm{ant}}$-depleted water would nevertheless result in a net $C_{a n t}$ reemergence if the water were to have acquired $\mathrm{C}_{\mathrm{ant}}$ locally from the downward diffusive flux. This contamination is common for these diagnostics.

\section{Results}

\section{a. Subduction-obduction of volume}

We begin with a consideration of the instantaneous subduction and obduction rates (which include the exchange between the mixed layer and the seasonal 
TABLE 1. Globally integrated transport of volume and $C_{a n t}$ across the base of the mixed layer. Net upward transport is defined as obduction minus subduction. Numbers in parentheses are instantaneous subduction and obduction defined by Eq. (1).

\begin{tabular}{lccc}
\hline \hline & Obduction & Subduction & Net upward \\
\hline $\begin{array}{l}\text { Volume } \\
\text { transport (Sv) }\end{array}$ & $369.9(1983)$ & $-369.0(-1983)$ & $0.9(0.0)$ \\
$\begin{array}{c}\mathrm{C}_{\text {ant }} \text { transport } \\
\left(\mathrm{PgC} \mathrm{yr}^{-1}\right)\end{array}$ & $4.50(28.7)$ & $-4.96(-29.1)$ & $-0.47(-0.39)$ \\
\hline
\end{tabular}

pycnocline) in the model calculated using Eq. (1). Positive (downward) and negative (upward) values are summed up separately to obtain the instantaneous subduction and obduction rates. For both instantaneous subduction and obduction, the annual-mean rates obtained are $1983 \mathrm{~Sv}$ (see Table 1). Next the Lagrangian diagnostics are used to identify the subduction rates. By this we mean exchange between the mixed layer and the permanent pycnocline and thereby subduction rates for water masses that stay isolated from the surface for more than $1 \mathrm{yr}$. Using this Lagrangian filter, we identify a subduction rate of $369.0 \mathrm{~Sv}$ and an obduction rate of $369.9 \mathrm{~Sv}$, reflecting the global balance between the subduction and obduction rates in the climatological state. Thus, we find that approximately $19 \%$ of the total (instantaneous) volume transport across the $\mathrm{ML}_{\text {base }}$ accounts for the ventilation of the main pycnocline over the time scales of a year and longer, while the remaining $81 \%$ (1613 1614 Sv) is exchanged seasonally between the surface mixed layer and the seasonal pycnocline. This result is comparable with the findings of Blanke et al. (2002), where they estimated a global ventilation rate to be $324 \mathrm{~Sv}$ using monthly model output from somewhat different configuration of the OPA model. If we use $\mathrm{TR}_{0}=0.01 \mathrm{~Sv}$ for prescribed transport maximum instead of $0.005 \mathrm{~Sv}$, the resultant Lagrangian-filtered subduction-obduction rates are 369.5-370.8 Sv with net upward transport of $1.4 \mathrm{~Sv}$, suggesting better convergence of the Lagrangian method by increasing the number of particles (i.e., a stricter $\mathrm{TR}_{0}$ threshold value). If we choose instead $\Delta \sigma_{0}=0.03$ for the MLD definition for the case of $\mathrm{TR}_{0}=0.01 \mathrm{~Sv}$, the Lagrangian-filtered subduction-obduction rates are $400.9-401.7 \mathrm{~Sv}$ with a net upward transport of $0.8 \mathrm{~Sv}$. Although the separate subduction and obduction rate components both increase for the larger MLD threshold definition, the net transport exhibits only small changes.

The spatial structure of the annual-mean net upward transport (obduction + subduction) in Fig. 1a largely shows negative values (downward transport; subduction) in the subtropics corresponding to downward Ekman pumping and positive values (upward transport; obduction) in the equatorial and subpolar regions where equatorial upwelling and Ekman suction is sustained by large-scale wind patterns, respectively. Strong upward transport also occurs along the eastern boundaries of several basins (corresponding to coastal upwelling regions). The western boundary currents and the Antarctic Circumpolar Current show banded structures of pairs of strong downward and upward transports. These can be considered as the formation and reemergence of major water masses including mode waters, whose formation history is closely related with strong oceanic fronts.

The subduction and obduction rates can be divided into four components corresponding to the right-hand side terms of Eq. (1): MLD tendency term and vertical, meridional, and zonal transport terms (Figs. 1b-e). The spatial structure of the net transport is mainly determined by the MLD tendency term (Fig. 1b). One of the clearest exceptions is the strong obduction along the equator, which is largely due to the vertical transport term very close to the equator (Fig. 1c) as well as to the meridional transport term on both the northern and southern flanks of the domed isopycnals near the equator (Fig. 1e). The contribution from the MLD tendency term is small in the equatorial regions, where the temporal change of MLD is relatively small throughout the year. The horizontal transport term is large in the western boundary currents and the Antarctic Circumpolar Current regions (Figs. 1d,e), and the vertical transport term is comparable to or even larger than the MLD tendency term in the polar regions of the Southern Ocean near the Antarctic continent (Figs. 1b,c).

Globally integrated contributions from each term are listed in Table 2. The MLD tendency term is the largest for both subduction and obduction, but the proportion is larger for subduction, accounting about $68 \%$ of the total subduction and about $44 \%$ of the total obduction. The horizontal (zonal + meridional; 17\%) and vertical transport terms $(15 \%)$ contribute comparably to the remaining $32 \%$ of the total subduction. For the case of obduction, the contribution from horizontal transport $(33 \%)$ is somewhat larger than that from vertical transport $(23 \%)$. Only the MLD tendency term contributes net downward volume transport, and the other three transport terms contribute net upward transport.

It is important to emphasize that the MLD tendency term and thus the total subduction and obduction rates have very strong seasonality. Time series of globally integrated subduction rates show clear biannual peaks in late winters of both hemispheres (late March and late September), when deeply developed winter mixed layers shoal rapidly (Figs. 2a,c). Obduction rates also show biannual peaks during times when the mixed layer 
(a) Volume transport across MLbase

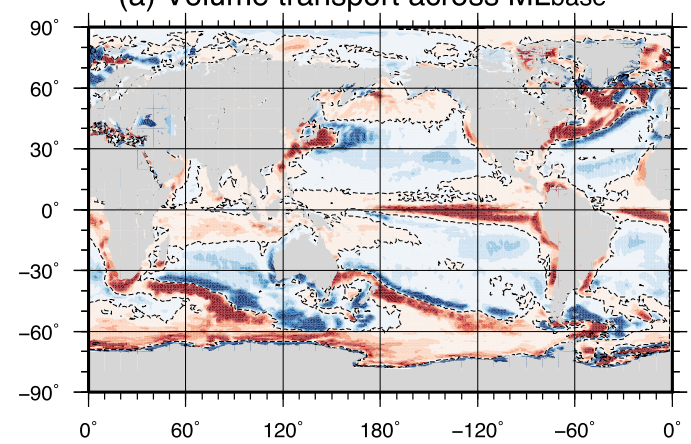

(b) $\mathrm{dh} / \mathrm{dt}$

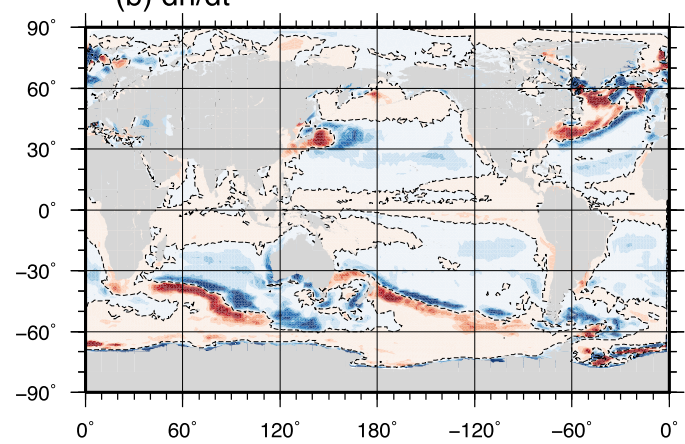

(d) $u \partial_{y} h$

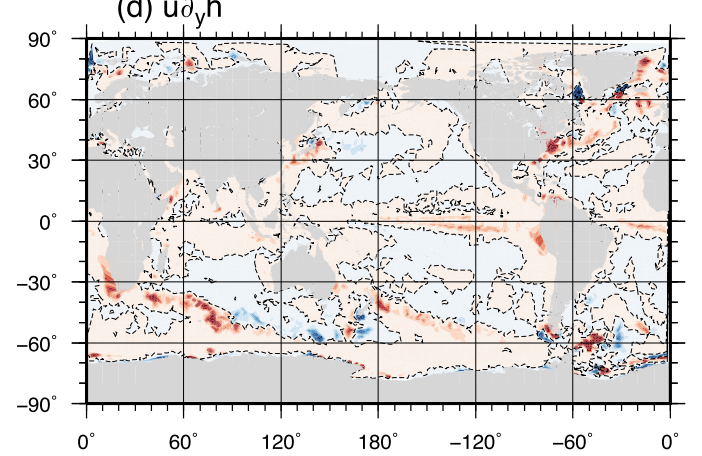

(c) $w$

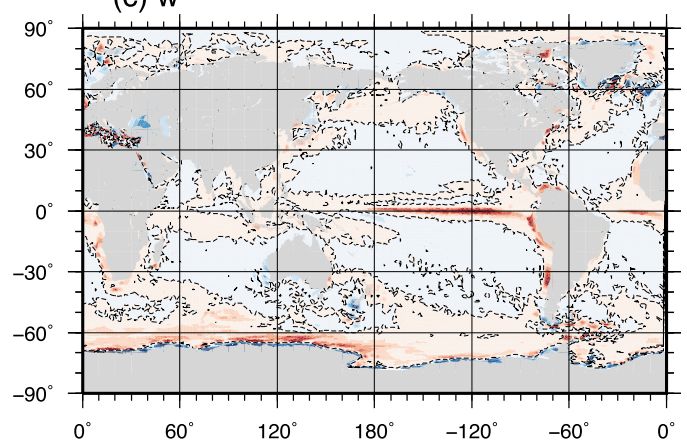

(e) $v \partial_{x} h$

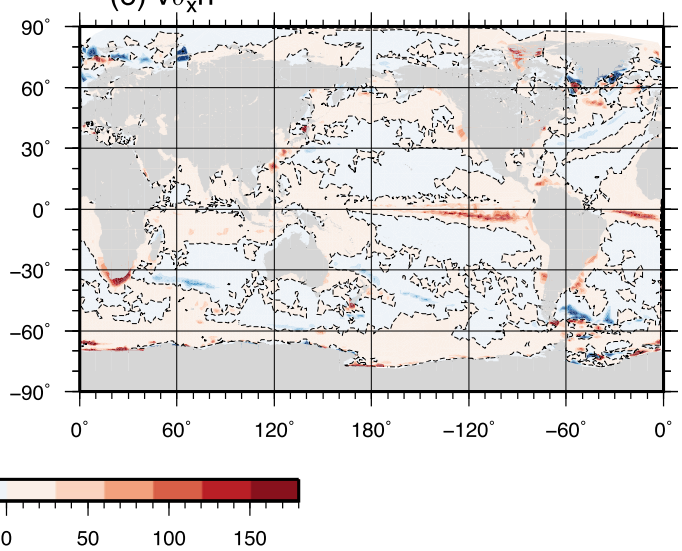

$\begin{array}{lllllll}-150 & -100 & -50 & 0 & 50 & 100 & 150\end{array}$

subduction/obduction rate (positive upward) [m/yr]

FIG. 1. Spatial distribution of annual-mean net-volume transport (obduction - subduction) across the $\mathrm{ML}_{\text {base }}$ $\left(\mathrm{m} \mathrm{yr}^{-1}\right)$ for (a) total and contributions from (b) MLD tendency term, (c) vertical, (d) zonal, and (e) meridional transport terms of Eq. (1). Positive values denote upward transport of volume.

gets deeper but smaller in magnitude compared with subduction (Figs. 2a,b). The contribution from the MLD tendency term is smaller for obduction, as mentioned above. However, the seasonal variation of total transport is mostly determined by the MLD tendency term for both obduction and subduction. This "Stommel demon" (Stommel 1979) behavior is the basis for the simplified kinematic diagnostics of subduction that assumes that only the month of maximal MLD is important. One of the advantages of the approach used in this study is that it does not assume that only the month of maximal MLD is important, and there is no need to find the maximal MLD locally or to use a specific month to estimate subduction and obduction rates.

\section{b. Subduction-obduction of $C_{a n t}$}

\section{DISTRIBUTION PATTERN}

Next we turn our attention to the subduction and obduction of $\mathrm{C}_{\mathrm{ant}}$ over the year 1995, taking into account the full seasonal cycle. The physical transports considered in Fig. 1 are multiplied locally at the $\mathrm{ML}_{\text {base }}$ by the local 
TABLE 2. Volume transport (Sv) and $\mathrm{C}_{\mathrm{ant}}$ transport in parentheses $\left(\mathrm{PgC} \mathrm{yr}^{-1}\right)$ for each component consisting of obduction, subduction, and net upward transport.

\begin{tabular}{lccc}
\hline \hline & Obduction & Subduction & Net upward \\
\hline Zonal & $70.4(0.89)$ & $-28.2(-0.30)$ & $42.3(0.58)$ \\
Meridional & $52.2(0.66)$ & $-32.9(-0.40)$ & $19.3(0.26)$ \\
Vertical & $83.3(0.96)$ & $-55.6(-0.73)$ & $27.7(0.23)$ \\
MLD & $164.0(2.00)$ & $-252.4(-3.53)$ & $-88.4(-1.54)$ \\
Total & $369.9(4.50)$ & $-369.0(-4.96)$ & $0.9(-0.47)$ \\
\hline
\end{tabular}

DIC $_{\text {ant }}$ concentration to arrive at a transport of $\mathrm{C}_{\mathrm{ant}}$. Following the sequence of calculations considered previously for physical subduction, we find that the total instantaneous $\mathrm{C}_{\mathrm{ant}}$ transports including the seasonal components are $29.1 \mathrm{PgCyr}^{-1}$ for subduction and 28.7 $\mathrm{PgC} \mathrm{yr}^{-1}$ for obduction (Table 1). Upon application of the Lagrangian diagnostics to identify the fraction of local subduction and obduction that involves transit times greater than $1 \mathrm{yr}$ below the $\mathrm{ML}_{\text {base, }}$, we obtain rates of 4.96 $\mathrm{PgC} \mathrm{yr}^{-1}$ for subduction and $4.50 \mathrm{PgC} \mathrm{yr}^{-1}$ for obduction, with net downward transport of $0.47 \mathrm{PgC} \mathrm{yr}^{-1}$. This tells us that the exchanges with the seasonal pycnocline alone account for about $24 \mathrm{PgC} \mathrm{yr}^{-1}$ of the subduction and obduction rates. This can be interpreted to reflect approximately $25 \%$ of the global WOCE-era interior $\mathrm{C}_{\text {ant }}$ inventory (106 PgC; Key et al. 2004; $94.2 \mathrm{PgC}$ in 1995 for this model) residing in the seasonal pycnocline and being seasonally exposed to the atmosphere while in the mixed layer. If we use $\mathrm{TR}_{0}=0.01 \mathrm{~Sv}$, the resulting Lagrangian-filtered $\mathrm{C}_{\mathrm{ant}}$ subduction-obduction rates are 4.97-4.51 $\mathrm{PgC} \mathrm{yr}^{-1}$ with net downward transport of
$0.46 \mathrm{PgCyr}^{-1}$. If we choose $\Delta \sigma_{0}=0.03$ for the MLD definition for the case of $\mathrm{TR}_{0}=0.01 \mathrm{~Sv}$, the Lagrangianfiltered $\mathrm{C}_{\mathrm{ant}}$ subduction-obduction rates are $5.01-4.48 \mathrm{PgC} \mathrm{yr}^{-1}$ with net downward transport of $0.53 \mathrm{PgC} \mathrm{yr}^{-1}$. These are almost the same as the case with $\Delta \sigma_{0}=0.01$ and $\mathrm{TR}_{0}=$ $0.005 \mathrm{~Sv}$. Therefore, the main results reported in this study are not sensitive to, or an artifact of, the choice of $\Delta \sigma_{0}=0.01$ threshold for this study.

We consider in Fig. 3 the spatial structures of the net $\mathrm{C}_{\mathrm{ant}}$ transport across the $\mathrm{ML}_{\text {base }}$ for 1995 , along with the decomposition of the different contributing terms, revealing structures that are in many ways similar to the physical transports seen in Fig. 1. The contribution from the MLD tendency term is largest for $\mathrm{C}_{\mathrm{ant}}$ (Fig. 3b), mirroring what was found for volume transport. The spatial structure of the gas exchange of $\mathrm{C}_{\mathrm{ant}}$ is also shown in Fig. $3 \mathrm{f}$ for comparison. Transport of $\mathrm{C}_{\mathrm{ant}}$ across the $\mathrm{ML}_{\text {base }}$ reveals much more of a rich structure than the transport across the air-sea interface, reflecting more the underlying dynamical structures. When integrated over the globe, the net downward transport of $\mathrm{C}_{\text {ant }}$ into the permanent pycnocline is $0.47 \mathrm{PgCyr}^{-1}$ (Table 1), which is about a quarter of globally integrated uptake of $\mathrm{C}_{\mathrm{ant}}$ by gas exchange of $2.04 \mathrm{PgC} \mathrm{yr}^{-1}$ for the year 1995 .

When integrated over latitudinal bands, the subtropics of both hemispheres reveal net subduction, and the tropics reveal net obduction (Table 3). Polar regions of both hemispheres show very small net $\mathrm{C}_{\mathrm{ant}}$ transport across the $\mathrm{ML}_{\mathrm{base}}$. The inventory change in the Southern Ocean is relatively small compared to the largest air-sea $\mathrm{C}_{\text {ant }}$ flux, which implies net $\mathrm{C}_{\mathrm{ant}}$ transport to the north
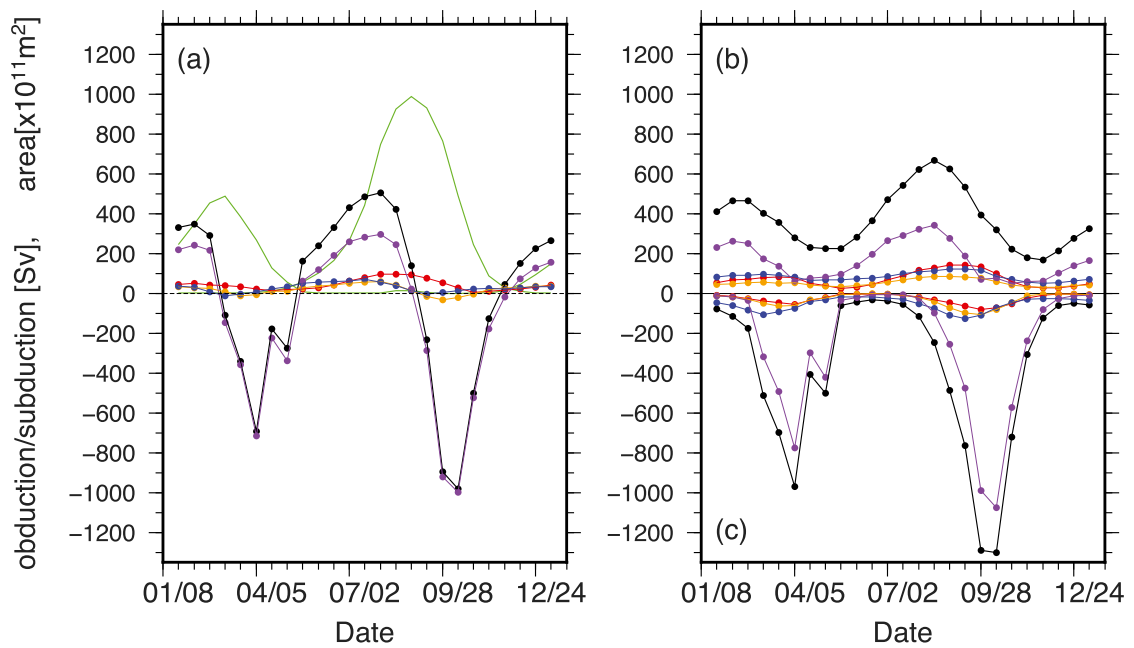

FIG. 2. Time series of volume transport across the $\mathrm{ML}_{\text {base }}$ for (a) net upward transport, (b) obduction, and (c) subduction. Positive values denote upward transport. Colors denote the total (black) and contributions from zonal (red), meridional (orange), and vertical (blue) transport terms and MLD tendency term (purple). The green line in (a) denotes the integrated area of grid points where MLD is deeper than $85 \mathrm{~m}$. 

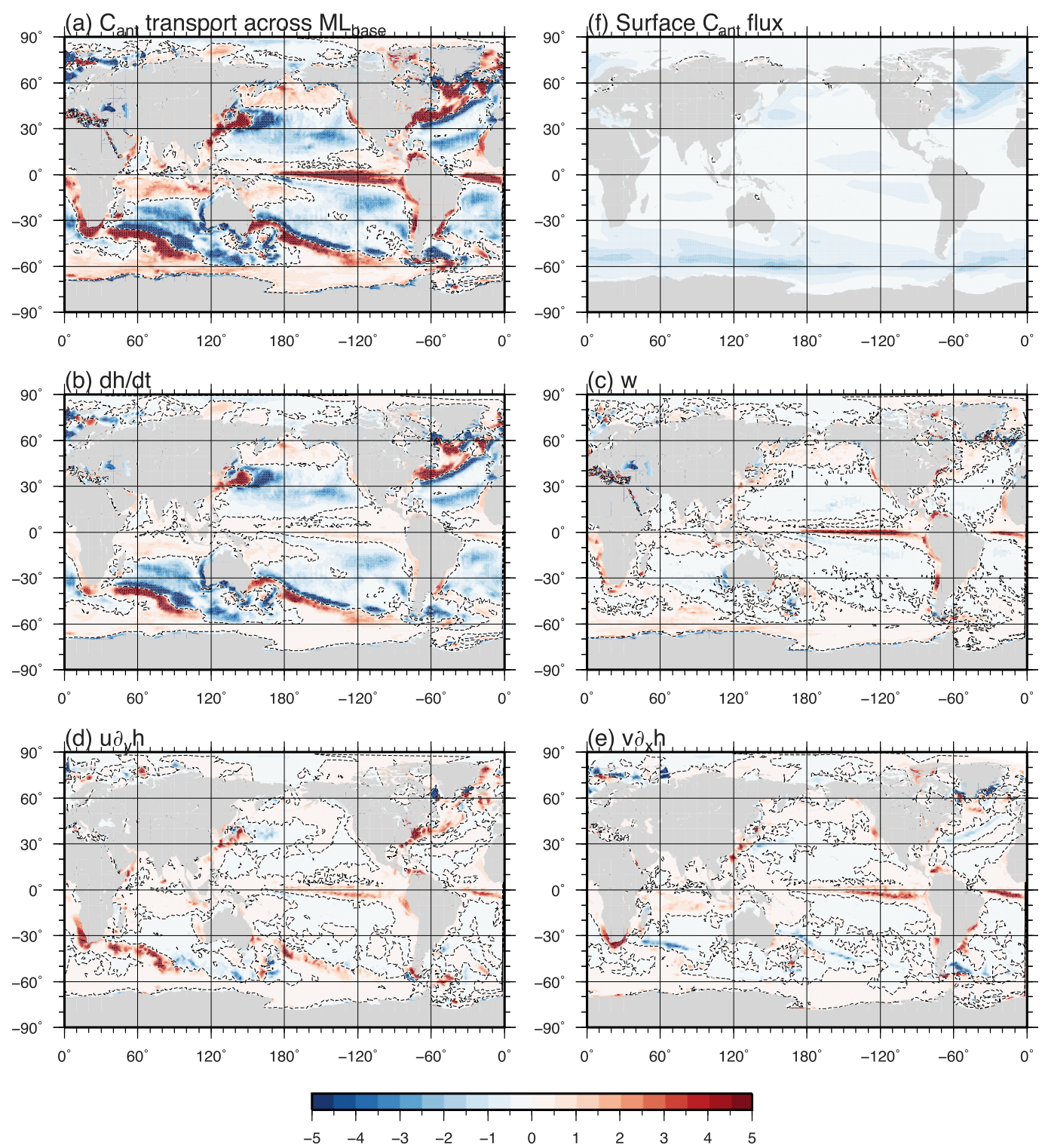

$\mathrm{C}_{\text {ant }}$ subduction/obduction rate (positive upward) $\left[\mathrm{mol} / \mathrm{m}^{2} / \mathrm{yr}\right]$

FIG. 3. As in Fig. 1, but for $\mathrm{C}_{\mathrm{ant}}$ transport $\left(\mathrm{molC} \mathrm{m} \mathrm{m}^{-2} \mathrm{yr}^{-1}\right)$. Positive values denote upward transport of $\mathrm{C}_{\mathrm{ant}}$. (f) The air-sea anthropogenic $\mathrm{CO}_{2}$ gas exchange $\left(\mathrm{molC} \mathrm{m}^{-2} \mathrm{yr}^{-1}\right)$. In (f), negative values denote $\mathrm{CO}_{2}$ update by the ocean, for consistency with the definition of reemergence of $\mathrm{C}_{\text {ant }}$ (obduction) as a positive quantity.

across $44^{\circ} \mathrm{S}$. The annual $\mathrm{C}_{\text {ant }}$ inventory change is large in the main pycnocline of the southern and northern subtropics, where the net downward $\mathrm{C}_{\mathrm{ant}}$ transport across the $\mathrm{ML}_{\text {base }}$ is large. The $\mathrm{C}_{\mathrm{ant}}$ inventory change in the equatorial pycnocline (ML) is large (small) in spite of the large net upward transport across $\mathrm{ML}_{\text {base }}$, suggesting large lateral input from (output to) the subtropics.

Density-binned $\mathrm{C}_{\mathrm{ant}}$ subduction and obduction rates for each latitudinal band and for the global ocean are shown in Fig. 4 to illustrate the water mass structure of subduction and obduction. Along with similar analysis for each basin (not shown), this figure suggests clear correspondence of the peak subduction densities with the well-known mode waters (e.g., Hanawa and Talley

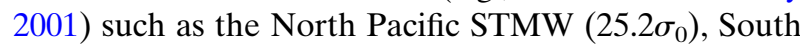
Pacific eastern STMW (25.3 $\left.\sigma_{0}\right)$, Subantarctic Mode Water (26.6-27.1 $\sigma_{0}$ in Fig. 4e), and the Antarctic Intermediate Water (27.20 $\sigma_{0}$ in Fig. $\left.4 \mathrm{f}\right)$. Integrated $\mathrm{C}_{\text {ant }}$ subduction and obduction per water mass using the coarse graining for water masses chosen by Iudicone et al. (2016) suggests a dominant contribution of tropical waters (TW) and STMW for $\mathrm{C}_{\text {ant }}$ obduction. STMW also 
TABLE 3. Latitudinally integrated $\mathrm{C}_{\mathrm{ant}}$ transport across the $\mathrm{ML}_{\text {base }}$ and the air-sea interface and annual inventory change rate in the $\mathrm{ML}$ and in the main pycnocline $\left(\mathrm{PgC} \mathrm{yr}^{-1}\right)$. The $\mathrm{C}_{\mathrm{ant}}$ concentration and air-sea $\mathrm{CO}_{2}$ flux in the year 1995 was used.

\begin{tabular}{|c|c|c|c|c|c|c|}
\hline \multirow[b]{2}{*}{ Lat } & \multirow[b]{2}{*}{ Obduction } & \multirow[b]{2}{*}{ Subduction } & \multirow[b]{2}{*}{ Net upward } & \multirow[b]{2}{*}{ Air-sea flux } & \multicolumn{2}{|c|}{ Inventory change } \\
\hline & & & & & $\mathrm{ML}$ & Pycnocline \\
\hline $49^{\circ}-90^{\circ} \mathrm{N}$ & 0.53 & -0.59 & -0.06 & -0.18 & 0.01 & 0.14 \\
\hline $18^{\circ}-49^{\circ} \mathrm{N}$ & 0.90 & -1.33 & -0.43 & -0.29 & 0.03 & 0.40 \\
\hline $18^{\circ} \mathrm{S}-18^{\circ} \mathrm{N}$ & 1.27 & -0.52 & 0.75 & -0.53 & 0.05 & 0.44 \\
\hline $18^{\circ}-44^{\circ} \mathrm{S}$ & 0.91 & -1.67 & -0.76 & -0.34 & 0.05 & 0.59 \\
\hline $44^{\circ}-90^{\circ} \mathrm{S}$ & 0.89 & -0.86 & 0.03 & -0.71 & 0.03 & 0.29 \\
\hline Total & 4.50 & -4.96 & -0.47 & -2.04 & 0.17 & 1.86 \\
\hline
\end{tabular}

provides the dominant contribution for subduction of $\mathrm{C}_{\text {ant }}$ (Table 4). It is worth noting that $63 \%(57 \%)$ of the global $\mathrm{C}_{\mathrm{ant}}$ obduction (subduction) occurs for densities less than $\sigma_{0}=26.6 \mathrm{~kg} \mathrm{~m}^{-3}$ (Fig. 5), and thereby for waters with densities less than that of the base of the directly ventilated thermocline and/or those with large $\mathrm{C}_{\text {ant }}$ inventory. This result implies the importance of the shallow overturning circulation in determining the interior inventory of $\mathrm{C}_{\mathrm{ant}}$ and is consistent with the results identified with the water mass transformation diagnostics of Iudicone et al. (2016).

Importantly, our Lagrangian-based diagnostics indicate that over global scales, the combined effects of subduction and obduction result in a net downward transport of $\mathrm{C}_{\mathrm{ant}}$ across the $\mathrm{ML}_{\text {base }}$ on the order of $0.47 \mathrm{PgC} \mathrm{yr}^{-1}$ in the model. To put this into context, the net uptake of $\mathrm{C}_{\mathrm{ant}}$ via gas exchange for this period was $2.04 \mathrm{PgC} \mathrm{yr}^{-1}$. The global inventory of $\mathrm{DIC}_{\mathrm{ant}}$ for the model in 1995 was $94.22 \mathrm{PgC}$, of which $8.22 \mathrm{PgC}$ was above the bowl depth (deepest winter mixed layer depth), and 86.0 PgC was below this horizon. The $\mathrm{DIC}_{\text {ant }}$ inventory increase due to the $\mathrm{C}_{\mathrm{ant}}$ uptake via gas exchange was $0.17 \mathrm{PgC} \mathrm{yr}^{-1}$ above the bowl depth and $1.86 \mathrm{PgC} \mathrm{yr}^{-1}$ below it. The increase of $1.86 \mathrm{PgC} \mathrm{yr}^{-1}$ in the permanent pycnocline should be transferred through the $\mathrm{ML}_{\text {base }}$, of which $0.47 \mathrm{PgCyr}^{-1}$ is accounted for by the net subduction. The residual of a net transfer approximately $1.40 \mathrm{PgC} \mathrm{yr}^{-1}$ downward from the mixed layer must be accounted for by vertical mixing, as our definition of $\mathrm{C}_{\mathrm{ant}}$ precludes a biological contribution. This important role of diffusion across the $\mathrm{ML}_{\text {base }}$ has recently been reported in the dynamical study of $\mathrm{C}_{\text {ant }}$ uptake using Eulerian subduction diagnostics of Bopp et al. (2015).

Our results are consistent with those of Bopp et al. (2015) in arguing for a first-order role of diffusion in the net transfer of $C_{a n t}$ from the ML to the ocean interior. Bopp et al. (2015) used a somewhat different configuration of the NEMO-LIM-PISCES model and evaluated $\mathrm{C}_{\mathrm{ant}}$ subduction using an online diagnostic method in an Eulerian framework. Our offline $\mathrm{C}_{\text {ant }}$ subduction estimate is also based on Eulerian formulation but as a consequence of combining this with our Lagrangian approach enables us to distinguish seasonal entrainmentdetrainment with the subduction-obduction having a time scale longer than $1 \mathrm{yr}$. For a direct comparison with the results of Bopp et al. (2015), our Eulerian estimate (without the Lagrangian filter; Fig. 6b) suggests a $C_{a n t}$ transport of $0.60 \mathrm{PgC} \mathrm{yr}^{-1}$ downward by the vertical and horizontal transport (advection) terms of Eq. (1) and $0.21 \mathrm{PgCyr}^{-1}$ upward by the MLD tendency (entrainment) term with total transport of $0.39 \mathrm{PgC} \mathrm{yr}^{-1}$ downward. Our method does not explicitly isolate the eddy term, which is effectively included in the vertical and horizontal transport terms by the inclusion of the bolus velocities. The diffusion term is only obtained as a residual of $1.40 \mathrm{PgCyr}^{-1}$. Bopp et al. (2015) estimated $1.21 \mathrm{PgC} \mathrm{yr}^{-1}$ downward transport by advection, $0.43 \mathrm{PgCyr}^{-1}$ upward transport by eddy transfers, and $1.48 \mathrm{PgC} \mathrm{yr}^{-1}$ downward exchange by vertical mixing (the sum of the vertical diffusion and entrainment) under a surface net $\mathrm{C}_{\mathrm{ant}}$ flux of $2.47 \mathrm{PgC} \mathrm{yr}^{-1}$ from the atmosphere to the ocean. The sum of the advection and eddy terms is $0.78 \mathrm{PgC} \mathrm{yr}^{-1}$ ( $32 \%$ of the surface flux), which is comparable with our estimate of $0.60 \mathrm{PgCyr}^{-1}$ ( $29 \%$ of the surface flux). The vertical mixing term of amplitude $1.48 \mathrm{PgCyr}^{-1}$ is also comparable with our estimate of $1.20 \mathrm{PgC} \mathrm{yr}^{-1}$ (the sum of the entrainment term and the residual), accounting for $60 \%$ and $58 \%$ of the surface flux of each model. The proportion of the $\mathrm{C}_{\mathrm{ant}}$ transport accounted for by each term is quite different when the Lagrangian filter is applied (Figs. 3, 6). The MLD tendency term plays a dominant role after the application of the Lagrangian filter (Fig. 3b), illustrating the importance of considering the seasonal cycle of MLD and the associated subduction as with the Stommel demon framework (Stommel 1979). In contrast, the MLD tendency term of the Eulerian net transport (Fig. 6b) contributes little to the total net transport (Fig. 6a). The transports that include interactions with the seasonal pycnocline are clearly noisier than those that invoke the Lagrangian filter (Fig. 3a) due to seasonal variability in the velocity fields (Figs. 6c-e). 
(a) Global Ocean $\quad(-0.47 \mathrm{PgC} / \mathrm{yr}) \quad$ Surf.flx: $-2.04 \mathrm{PgC} / \mathrm{yr}(100.0 \%)$
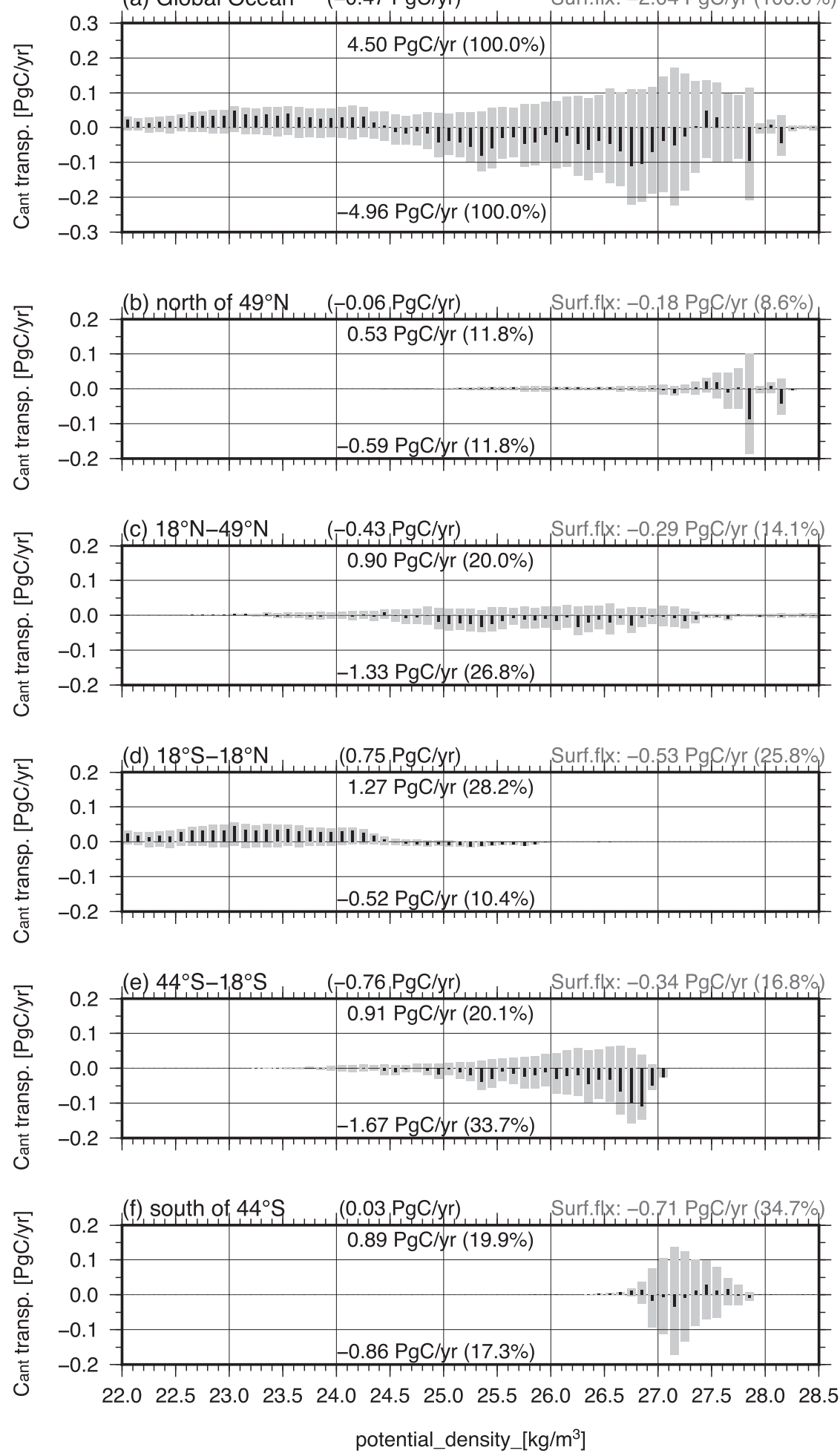

FIG. 4. Density structure of $\mathrm{C}_{\mathrm{ant}}$ subduction and obduction integrated (a) globally, (b) for the region north of $49^{\circ} \mathrm{N}$, (c) over $18^{\circ}-49^{\circ} \mathrm{N}$, (d) over $18^{\circ} \mathrm{S}-18 \mathrm{~N}$, (e) over $18^{\circ}-44^{\circ} \mathrm{S}$, and (f) south of $44^{\circ} \mathrm{S}$. The thick gray bars denote subduction and obduction, and the thin black bars denote net transport. 
TABLE 4. As in Table 3, but integrated over each water mass defined by potential density range $(\mathrm{TW}=$ tropical waters, STMW $=$ subtropical mode waters, SPMW = subpolar mode waters, IW = intermediate waters, and DW = deep waters).

\begin{tabular}{lcccrr}
\hline \hline Water mass & $\sigma_{0}$ range & Obduction & Subduction & Net upward & Air-sea flux \\
\hline TW & $\sigma_{0}<24.5$ & 1.48 & -0.60 & 0.88 & -0.57 \\
STMW & $24.5<\sigma_{0}<26.6$ & 1.36 & -2.22 & -0.86 & -0.59 \\
SPMW & $26.6<\sigma_{0}<27.1$ & 0.66 & -1.03 & -0.38 & -0.42 \\
IW & $27.1<\sigma_{0}<27.4$ & 0.42 & -0.40 & 0.03 & -0.29 \\
DW & $27.4<\sigma_{0}$ & 0.58 & -0.71 & -0.13 & -0.15 \\
Total & & 4.50 & -4.96 & -0.47 & -2.04 \\
\hline
\end{tabular}

For the case of the equatorial band $\left(18^{\circ} \mathrm{N}-18^{\circ} \mathrm{S}\right)$, we wish to emphasize here the large amplitude of reemergence of $\mathrm{C}_{\mathrm{ant}}$, defined as a net transfer through upwelling or obduction from the ocean interior to the surface mixed layer. The net upward transfer in our model is $0.75 \mathrm{PgC} \mathrm{yr}^{-1}$, with this quantity being larger than the uptake of $\mathrm{C}_{\mathrm{ant}}$ through gas exchange $\left(0.53 \mathrm{PgC} \mathrm{yr}^{-1}\right)$ considered as an integral over the equatorial band over 1995. Given that this reemergence reflects (via our Lagrangian filter) water that has been below the mixed layer for more than $1 \mathrm{yr}$, this reemergence is expected to reflect the large-scale intergyre exchange of pycnocline waters revealed for a similar configuration of the same model in Rodgers et al. (2003). That is, this large reemergence for surface equatorial Pacific waters primarily has subtropical origins that are rich in $\mathrm{C}_{\mathrm{ant}}$, with the supply from the South Pacific being larger than from the North Pacific. In fact, two-thirds of the Lagrangian particles and $\mathrm{C}_{\mathrm{ant}}$ transport obducting-upwelling in the equatorial Pacific $\left(5^{\circ} \mathrm{S}-5^{\circ} \mathrm{N}, 80^{\circ}-180^{\circ} \mathrm{W}\right)$ originate in the Southern Hemisphere in our model. Large compensating outflow is expected in the equatorial ML, where there is only a small annual accumulation of $\mathrm{C}_{\mathrm{ant}}$ in spite of the large reemergence along with the large uptake through gas exchange, forming the upper branch of the shallow overturning circulation.

In the subtropics, the western boundary currents transport substantial quantities of $\mathrm{C}_{\mathrm{ant}}$, much of which then reemerges in the western boundary regions. The story presented here is consistent with the nutrient stream framework of Williams et al. (2006), where the importance of the induction (i.e., obduction) processes in transporting nutrient-rich upper thermocline water of the Gulf Stream into the surface mixed layer was emphasized. When the net upward transports are integrated only over the western boundary regions, the Kuroshio $\left(20^{\circ}-40^{\circ} \mathrm{N}, 120^{\circ}-160^{\circ} \mathrm{E}\right)$ and the Gulf Stream $\left(20^{\circ}-40^{\circ} \mathrm{N}, 40^{\circ}-80^{\circ} \mathrm{W}\right)$ regions amount to $0.22 \mathrm{PgC} \mathrm{yr}^{-1}$ $(12.5 \mathrm{~Sv})$ and $0.15 \mathrm{PgC} \mathrm{yr}^{-1}$ (9.3 Sv), respectively. Eulerian diagnostics (Fig. 6b) without the Lagrangian filter yield 0.14 and $0.11 \mathrm{PgC} \mathrm{yr}^{-1}$ of $\mathrm{C}_{\text {ant }}$ reemergence in the Kuroshio and Gulf Stream regions. Thus, both diagnostics of obduction clearly indicate the preferential occurrence of obduction in the western boundary regions. We wish to emphasize that although the Lagrangian filter typically yields reduced subduction and obduction rates relative to the unfiltered fields, here for the case of the Northern Hemisphere western boundary currents the fluxes are larger with the Lagrangian filter.

\section{c. Renewal time scales and interior pathways}

The analysis thus far has focused on the patterns or rates of exchange of $\mathrm{C}_{\mathrm{ant}}$ across the $\mathrm{ML}_{\text {base }}$. However, the full power of the Lagrangian diagnostics lies in connecting emergence patterns with renewal time scales. Renewal time scales are intended to reflect the time that water masses spend in the ocean interior between subduction and re-entrainment through obduction into the mixed layer. As an example, the water mass structure and a distribution map of mean and median travel time of particles within the ocean interior along their pathways (i.e., between subduction and obduction regions) are shown in Figs. 7 and 8, respectively. The classical renewal time defined as the ratio of the volume of a density layer to the subduction rate for that density layer is also shown in Fig. 7. The average travel times of all the subducting and obducting particles are calculated as 105.7 and $124.4 \mathrm{yr}$, respectively. The time scale of particles

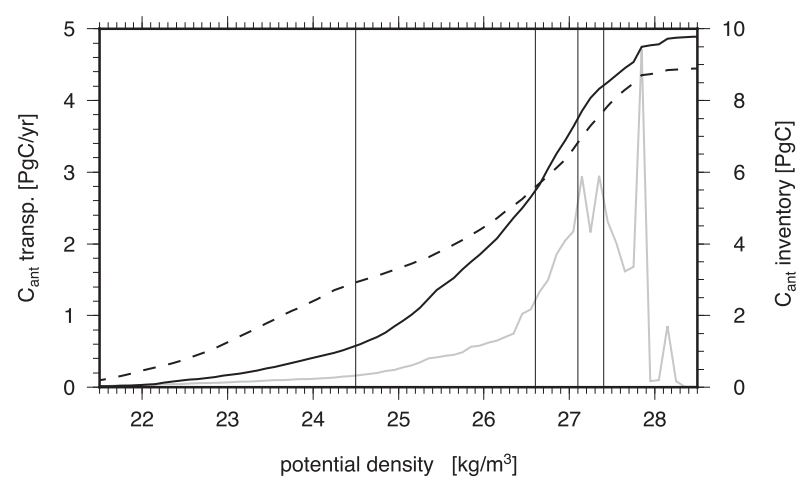

FIG. 5. Cumulative $\mathrm{C}_{\mathrm{ant}}$ subduction (solid line) and obduction (dashed line) integrated from the lightest densities over the global domain. The $\mathrm{C}_{\mathrm{ant}}$ inventory for each density bin (gray line) is overlaid. 


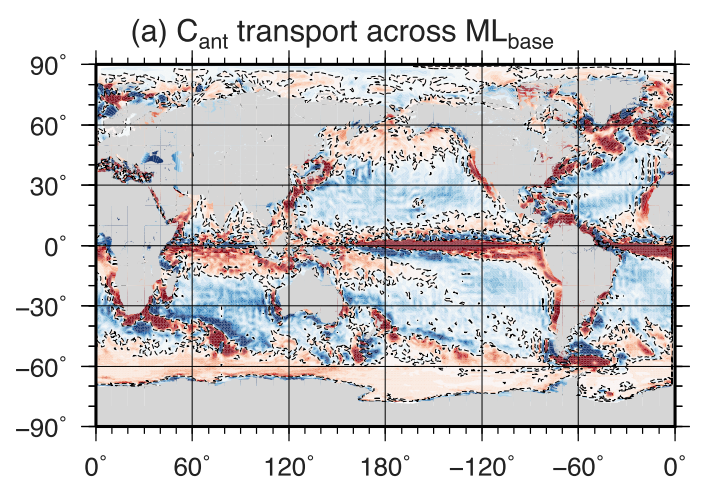

(b) $\mathrm{dh} / \mathrm{dt}$

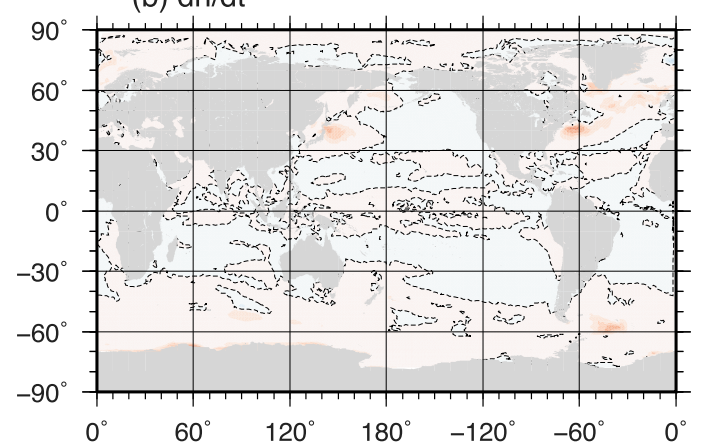

(d) $u \partial_{y} h$
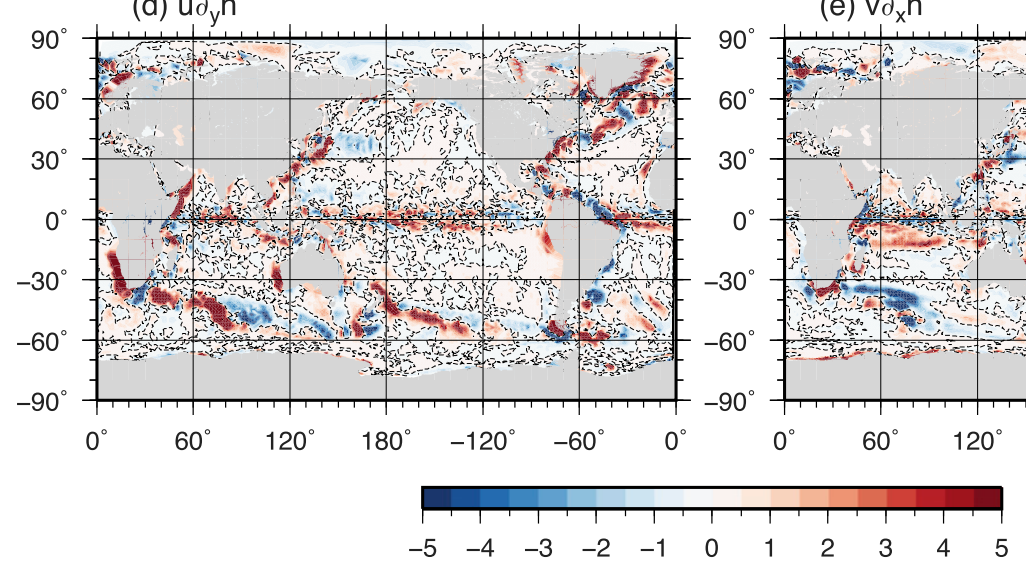

$\mathrm{C}_{\text {ant }}$ subduction/obduction rate (positive upward) $\left[\mathrm{mol} / \mathrm{m}^{2} / \mathrm{yr}\right]$ (c) w

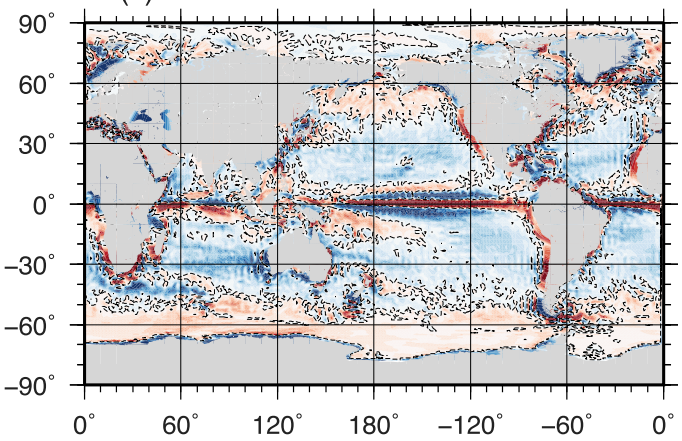

(e) $v \partial_{x} h$

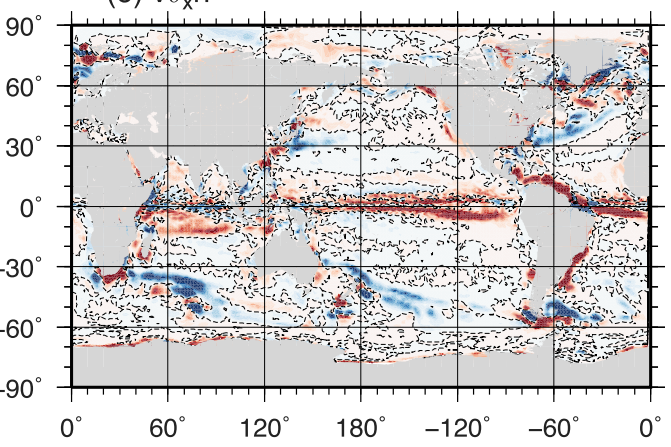

FIG. 6. As in Fig. 3, but for instantaneous $\mathrm{C}_{\mathrm{ant}}$ transport [molC $\mathrm{m}^{-2} \mathrm{yr}^{-1}$; without (f)].

subducting in the subtropical density range is on the order of $10 \mathrm{yr}$, indicating relatively rapid reemergence consistent with observationally based estimates (Suga et al. 2008; Kwon and Riser 2004). The mean travel time of obducting particles is on the order of $100 \mathrm{yr}$ for most density ranges; however, the median travel time of obducting particles is on the order of $10 \mathrm{yr}$, with this being of significantly shorter duration than the mean travel time. This also suggests a dominant contribution from particles of subtropical origin for the obduction structure, with a contribution from a relatively small number of particles with longer travel times. When the western boundary reemergence regions are sampled, the median (mean) travel times of the obducting particles are $\sim 5.8 \mathrm{yr}$ ( $\sim 65.5 \mathrm{yr})$ for the Kuroshio region and $\sim 5.0 \mathrm{yr}(\sim 81.5 \mathrm{yr})$ for the Gulf Stream region (Fig. 8). The longer mean travel time for the Gulf Stream region despite shorter median travel time relative to the Kuroshio region reflects a larger contribution of particles subducted in the Southern Hemisphere for the Gulf Stream, consistent with the nutrient stream framework of Williams et al. (2006). The Southern Ocean is characterized by a large number of obducting particles with very old water particles (Figs. 8b,d). Obduction of very old water particles 


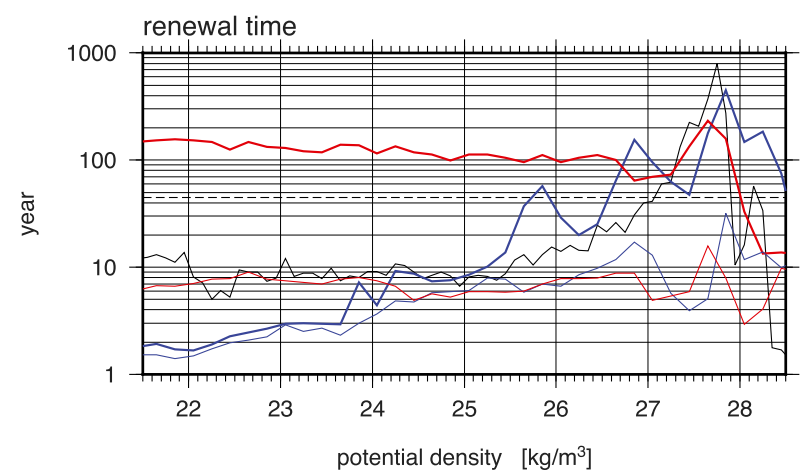

FIG. 7. Mean (thick lines) and median (thin lines) travel time of particles for forward (subduction; blue) and reverse (obduction; red) Lagrangian calculation. Density at the time of subduction and obduction was used for density binning. The classical renewal time (black) for each density bin is overlaid.

also preferentially occurs in the equatorial regions and subpolar regions of the Northern Hemisphere.

As mentioned in the introduction, the time scale for the reemergence should be rapid relative to that of anthropogenic transient in order for reemergence to be effective in contributing to carbon-climate feedbacks. The terminology "carbon climate feedback" considered here refers to feedbacks through the Revelle factor (Revelle and Suess 1957), namely, through the impact of perturbations to DIC concentrations. This is distinct from perturbations that could occur through temperature perturbations. More specifically, an ocean with obducting waters having zero $\mathrm{C}_{\text {ant }}$ content should be expected to have less resistance to uptake of carbon from the atmosphere than an ocean with obducting waters having nonzero $\mathrm{C}_{\mathrm{ant}}$ content. As an idealized scaling argument [following that presented in Iudicone et al. (2016)], we assume an exponential increase of an atmospheric tracer $c_{\mathrm{atm}}=\exp (t / \tau)$ and that the tracer concentration in the mixed layer tracks that of the atmosphere [i.e., $c_{\mathrm{ml}}=C_{0} \times \exp (t / \tau)$ ]; then, the ratio between the tracer in the mixed layer $c_{\mathrm{ml}}$ and that of the reemergent water $\left[c_{\mathrm{obd}}=C_{0} \times \exp \left(t^{\prime} / \tau\right)\right.$, where $t^{\prime}$ is the time of the subduction] is $c_{\mathrm{obd}} / c_{\mathrm{ml}}=\exp \left[-\left(t-t^{\prime}\right) / \tau\right]$. This means the reemergence of waters that spend more than $\tau$ yr below the $\mathrm{ML}_{\text {base }}\left[\left(t-t^{\prime}\right)>\tau\right]$ will have as an upper bound $37 \%$ of $c_{\mathrm{ml}}$, and thus their contribution to the tracer budget within the mixed layer is less significant. The median ocean interior travel time of obducting particles is generally less than $10 \mathrm{yr}$ (Fig. 7), with this being much smaller than the characteristic time scale of atmospheric $\mathrm{C}_{\mathrm{ant}}$ rise ( $\tau=$ about $45 \mathrm{yr}$ ), and thus one can expect an important role for reemergence in impeding the air-sea fluxes of carbon relative to what one would expect in the absence of reemergence, thereby contributing to a positive carbon-climate feedback, especially where there is a large and rapid reemergence as in the subtropics. In the equatorial and polar regions, where there is strong surface uptake (Fig. 3f), the reemergence time scale is generally too long for the reemergence to be effective (Fig. 8).

We wish to reiterate here that individual Lagrangian particles used to calculate trajectories are not intended to represent a simulation of individual carbon molecules. The modulation of the Lagrangian time scales quantified here by diffusion processes is left as a subject for future investigation and will require extending the current functionality of the Ariane code base. The work here focusing on a kinematic approach to subduction is intended to be complementary to the thermodynamic approach of Walin (1982) applied to the subduction and obduction of preindustrial carbon by Iudicone et al. (2011). The kinematic approach here adds value in that the spatial structures of subduction and obduction are readily identified and offer the possibility of extension through the application of the Ariane Lagrangian diagnostics.

\section{Discussion}

We set out to evaluate a potential role of the overturning circulation in sustaining substantial reemergence of $\mathrm{C}_{\mathrm{ant}}$ across the $\mathrm{ML}_{\mathrm{base}}$, applying a kinematic suite of diagnostics of subduction and obduction to output from a climatological ocean circulation state. As part of our effort to identify the connection with the overturning circulation, we opted to choose subduction and obduction diagnostics that facilitate a focus on the net exchange between the mixed layer and the permanent pycnocline and to exclude exchange that occurs only with the seasonal pycnocline. For this reason, we chose the Ariane Lagrangian diagnostics of Blanke et al. (2002) and effectively extended the diagnostics of that study to a consideration of subduction and obduction of $\mathrm{C}_{\mathrm{ant}}$.

Although our diagnostic tools are independent of the Eulerian diagnostics of Nakano et al. (2015) and the water mass transformation diagnostics of Iudicone et al. (2016), our method yields results that are consistent with both of these studies in emphasizing the importance of the overturning circulation in prescribing the ocean $\mathrm{C}_{\mathrm{ant}}$ inventory. What is new here is that we have provided a net global rate for reemergence in connection with the overturning circulation, with this being $4.50 \mathrm{PgC} \mathrm{yr}^{-1}$ for 1995. An important part of this is sustained by the relatively rapid renewal time scales of mode waters, namely, a relatively rapid succession (relative to anthropogenic perturbations to the climate system) of episodes of subduction and then obduction. The relatively rapid and 

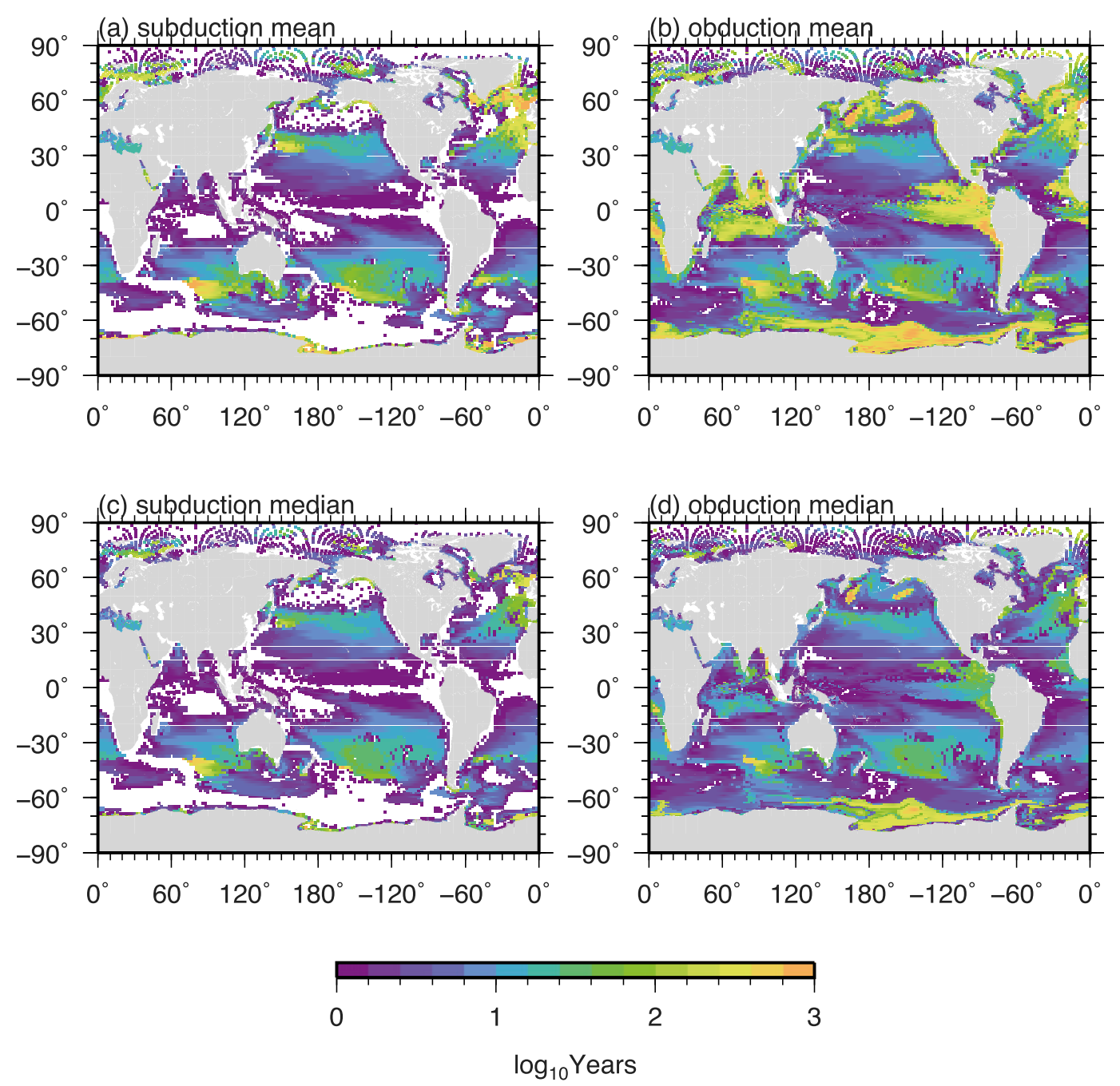

FIG. 8. Spatial distribution of (a),(b) mean and (c),(d) median travel time (in logarithmic years) of (left) subduction and (right) obduction particles within each grid box.

large amplitude of $\mathrm{C}_{\text {ant }}$ reemergence associated with the subtropical cells is consistent with the reemergence pathways emphasized by Nakano et al. (2015) and the bomb-radiocarbon reemergence pathways for the equatorial Pacific emphasized by Rodgers et al. (2004).

The significant $\mathrm{C}_{\mathrm{ant}}$ transport and upwelling through an "anthropogenic carbon stream" in the western boundary regions will have an impact on the carbon chemistry of the ocean interior as well as the mixed layer on interannual to decadal time scales. In fact, Oka et al. (2015) reported the decadal modulation of the acidification rate in the downstream region of the North Pacific Subtropical Mode Water formation region, based on observational data. The western boundary obduction should also be expected to impact the acidification of coastal regions that are directly adjacent to the western boundary current regions. The amplitudes of river runoff and continental discharge that have been suggested by Dai and Trenberth (2002) are in some regions of sufficient amplitude to be considered as contributors to coastal acidification. However, the magnitude of the global continental discharge is suggested to be $1.18 \pm$ $0.02 \mathrm{~Sv}$, and thus the physical obduction rate in the western boundary current regions may be at least an order of magnitude larger than the combined local river fluxes into the western boundary current. Kwon et al. (2014) estimated submarine groundwater discharge to be $3.8 \pm 1.0 \mathrm{~Sv}$, which may still be a fraction of the flux associated with obduction in the western boundary current. Of course, this does not mean the river input, continental discharge, and the submarine groundwater discharge are not of importance, but one should recognize the western boundary reemergence as a candidate for a first-order process in contributing to local ocean 
acidification. One of the factors determining the relative importance would be the exchange rate between coastal oceans and the western boundary currents. The balance between reemergence and river and groundwater inputs in driving coastal acidification could then depend on this exchange rate. Although western boundary current net obduction is known to occur (Qiu and Huang 1995), and the obducted waters can be expected to have a relatively elevated $\mathrm{C}_{\mathrm{ant}}$ content, it is our hope that the sensitivity of the results presented here to ocean model resolution can be explored in future studies.

Our results also implicate an important role for the diffusion of $\mathrm{C}_{\mathrm{ant}}$ downward across the $\mathrm{ML}_{\mathrm{base}}$, impacting water masses that obduct through their participation in overturning circulation structures. This may be particularly important over the Southern Ocean and in the subpolar North Atlantic, where our results suggest there is an apparent discrepancy between a net upward transport of $\mathrm{C}_{\mathrm{ant}}$ across the $\mathrm{ML}_{\text {base }}$ and substantial uptake of $\mathrm{C}_{\mathrm{ant}}$ via gas exchange may be explained by downward diffusion. We wish to emphasize that the globally integrated downward diffusive $C_{a n t}$ flux of 1.40 $\mathrm{PgC} \mathrm{yr}^{-1}$ across the base of the mixed layer relative to the net uptake by gas exchange of $2.04 \mathrm{PgC} \mathrm{yr}^{-1}$ should not be interpreted to mean that diffusion is a dominant mechanism for the transfer of $\mathrm{C}_{\mathrm{ant}}$ into the ocean interior. Rather, we wish to interpret diffusion as being a first-order process in a balance of several terms when considered over global scales and that this balance will surely vary by region. However, as diffusive exchanges of $\mathrm{C}_{\mathrm{ant}}$ were not saved as output diagnostics for the OPA runs considered here, we can only infer the net diffusive downward transfer of $C_{a n t}$ across the $M L_{b a s e}$, and the spatial structure of the exchange remains unresolved. Thus, a careful evaluation of the spatial patterns of the diffusive exchanges is beyond the scope of the present study, but it is our intention in our future extension of this work to address this question. Eddies could also provide a significant contribution to the regional and global $\mathrm{C}_{\mathrm{ant}}$ transport and water mass budget. However, the effect of eddies cannot be quantified explicitly with the use of relatively low-resolution model output used here. The evaluation of the $\mathrm{C}_{\mathrm{ant}}$ transport by eddies would also be an important step toward more complete understanding of the $\mathrm{C}_{\mathrm{ant}}$ subduction. In this regard, sensitivity of the methodology and result to the model resolution should also be evaluated, but we leave this as a subject for future study.

At first glance, the Lagrangian method might be faulted for not itself representing the effect of diffusion on a tracer such as $\mathrm{C}_{\mathrm{ant}}$. In fact, such a potential misunderstanding is averted when one considers that individual Lagrangian particles are not intended to simulate molecules of a passive tracer but rather to represent streamtubes of transport that are used to interpret the explicitly simulated $\mathrm{C}_{\mathrm{ant}}$ field. The Lagrangian diagnostics can be complemented by Eulerian diagnostics of diffusive processes, allowing one to quantify the diffusive transports of $C_{a n t}$ across the base of the mixed layer. In this way, the fact that the Lagrangian particles do not experience diffusion represents a strength of the method, as it provides us with a way to deconvolve the diffusive and subduction-obduction transports of $\mathrm{C}_{\mathrm{ant}}$ into and out of the mixed layer, while being faithful to an interpretation of subduction-obduction (filtering interactions with the seasonal thermocline) through the Lagrangian diagnostics.

We have chosen here to develop the new Lagrangianbased subduction and obduction diagnostics for a passive tracer $\mathrm{C}_{\mathrm{ant}}$ that is defined to have no sources or sinks in the ocean interior. However, the method developed and presented here is perfectly general and can thereby be applied to a wide range of biologically active tracers (nutrient) as well as to tracers that exhibit radioactive decay (e.g., dissolved inorganic ${ }^{14} \mathrm{C}$ ). For $\mathrm{C}_{\text {ant }}$ itself, a principal future challenge will be to deconvolve explicitly the interaction between transport and diffusive processes and benefit greatly from analyses of diffusive tendencies for this tracer. For biologically active tracers such as nitrate, biological sources and sinks will add an additional degree of complexity in the interpretation, with biological tendencies in addition to diffusive tendencies to be important. The effect of model resolution could also be evaluated by applying the methods to model outputs with different resolutions.

\section{Conclusions}

In this study, a new set of Lagrangian diagnostics have been developed and applied to quantifying $C_{a n t}$ exchange across the base of the mixed layer $\mathrm{ML}_{\text {base }}$ at the time of WOCE (year 1995). Our main finding is that the globally integrated net downward transport of $\mathrm{C}_{\mathrm{ant}}$ across the $\mathrm{ML}_{\text {base }}$ represents a residual of $2.04 \mathrm{PgC} \mathrm{yr}^{-1}$ of three terms that themselves make first-order contributions: (1) a net downward subduction of $4.96 \mathrm{PgC} \mathrm{yr}^{-1}$, (2) a net upward obduction rate of $4.50 \mathrm{PgC} \mathrm{yr}^{-1}$, and (3) a net downward diffusive flux of $1.40 \mathrm{PgC} \mathrm{yr}^{-1}$.

There are three key scientific interpretations that we wish to emphasize in the interpretation of these results. The first involves the substantial reemergence of $\mathrm{C}_{\mathrm{ant}}$ of $4.50 \mathrm{PgC} \mathrm{yr}^{-1}$ into the mixed layer from the permanent pycnocline over global scales through obduction over time scales of a decade. The $\mathrm{C}_{\mathrm{ant}}$ reemergence is largely balanced by $\mathrm{C}_{\text {ant }}$ subduction of comparable magnitude $\left(4.96 \mathrm{PgC} \mathrm{yr}^{-1}\right)$; however, the 
sufficiently rapid reemergence should be expected to impact the carbonate chemistry of the mixed layer and thereby the impedance of the ocean to future carbon uptake, relative to what one would expect if upwelling waters were to contain no $\mathrm{C}_{\text {ant }}$.

The second major result, related to the first, is that this important quantity of reemergence of $\mathrm{C}_{\mathrm{ant}}$ is directly connected to overturning circulation structures in the ocean. It is in fact these dynamical structures that impose the structure in $\mathrm{C}_{\text {ant }}$ reemergence, as can be seen in a comparison of Figs. 1 and 3. Much of the reemergence over the broad expanses of the subtropical and equatorial oceans $\left(45^{\circ} \mathrm{S}-45^{\circ} \mathrm{N}\right)$ occurs over time scales of a decade. We wish to highlight two components of the reemergence over $45^{\circ} \mathrm{S}-45^{\circ} \mathrm{N}$. On the one hand, the significant upwelling of $\mathrm{C}_{\mathrm{ant}}$-rich waters in the equatorial regions sustains a net supply of $\mathrm{C}_{\mathrm{ant}}$ upward across the $\mathrm{ML}_{\text {base }}$ that is significantly larger than the integrated net uptake of $\mathrm{C}_{\mathrm{ant}}$ by gas exchange over the same regions. This implicates the subtropical cell overturning structures, linking extraequatorial subduction regions and equatorial upwelling as being the dominant driver of the transient in $\mathrm{C}_{\mathrm{ant}}$ inventories in the equatorial oceans. This lends support to the idea of Ishii et al. (2009) that the subtropical cells play an important role in the supply of $\mathrm{C}_{\mathrm{ant}}$ to surface equatorial Pacific waters. Additionally, we have identified significant reemergence of $\mathrm{C}_{\mathrm{ant}}$ in western boundary current regions, with reemergence of $\mathrm{C}_{\mathrm{ant}}$ in these regions being significantly larger than local uptake of $\mathrm{C}_{\mathrm{ant}}$ via gas exchange over the same regions. This indicates that reemergence of $\mathrm{C}_{\mathrm{ant}}$ should play a first-order role in sustaining acidification in nearshore regions in the vicinity of western boundary currents. Nevertheless, these results associated with currents and fronts are strongly dependent on model resolution, since the model reproducibility (such as positions and strength) of currents and fronts is highly dependent on the model resolution. Further investigation with higher-resolution models with in situ data support will be necessary in this regard.

The third major result is that the downward diffusion of $\mathrm{C}_{\mathrm{ant}}$ across the $\mathrm{ML}_{\text {base }}$ is of first-order importance to understanding the pathways of global ocean $\mathrm{C}_{\mathrm{ant}}$ uptake, consistent with the previous findings of Bopp et al. (2015) using a similar model configuration. Although we did not have sufficient output diagnostics to identify the specific spatial patterns of diffusion across the $\mathrm{ML}_{\text {base}}$, we can infer from the Bopp et al. (2015) results using an ORCA2 configuration of NEMO with similar resolution that downward diffusion of $\mathrm{C}_{\mathrm{ant}}$ into Circumpolar Deep Water in the relatively unstratified Antarctic divergence region may help to account for the reemergence of $\mathrm{C}_{\mathrm{ant}}$ identified there with our obduction diagnostics. This could help to account for some of the reemergence of $\mathrm{C}_{\mathrm{ant}}$ identified over the Southern Ocean by Sallée et al. (2012).

Acknowledgments. We thank Matthew Thomas for his help in configuring the subduction diagnostics using Ariane. We thank the three anonymous reviewers and the editor for their constructive comments and criticism. The work of K. T. is supported through NSF Award OCE1155983 and through the Meteorological Research Institude's priority research fund for the study of ocean carbon cycle changes. The support of $\mathrm{K}$. B. R is through NOAA Awards NA17RJ2612 and NA08OAR4320752, which includes support through the NOAA Office of Climate Observations (OCO) as well as through NASA Award NNX14AL85G. D. I. was partially funded by the Flagship Project RITMARE-The Italian Research for the Sea-funded by the Italian Ministry of Education, University, and Research within the National Research Program 2001-13.

\section{REFERENCES}

Aumont, O., and L. Bopp, 2006: Globalizing results from ocean in situ iron fertilization studies. Global Biogeochem. Cycles, 20, GB2017, doi:10.1029/2005GB002591.

Blanke, B., and S. Raynaud, 1997: Kinematics of the Pacific Equatorial Undercurrent: A Eulerian and Lagrangian approach from GCM results. J. Phys. Oceanogr., 27, 1038-1053, doi:10.1175/1520-0485(1997)027<1038:KOTPEU>2.0.CO;2.

_- and N. Grima, 2011: Ariane Version 2.2.6. CNRS/IUEM/ Université de Bretagne Occidentale/IRD/Ifremer/Laboratoire de Physique des Océans, http://stockage.univ-brest.fr/ grima/Ariane/.

- S. Speich, G. Madec, and R. Mauge, 2002: A global diagnostic of interior ocean ventilation. Geophys. Res. Lett., 29, 1267, doi:10.1029/2001GL013727.

Bolin, B., and E. Eriksson, 1958: Changes in the carbon dioxide content of the atmosphere and sea due to fossil fuel combustion. The Atmosphere and the Sea in Motion: Scientific Contributions to the Rossby Memorial Volume, B. Bolin, Ed., Rockefeller Institute Press, 130-142.

Bopp, L., M. Lévy, L. Resplandy, and J. B. Sallée, 2015: Pathways of anthropogenic carbon subduction in the global ocean. Geophys. Res. Lett., 42, 6416-6423, doi:10.1002/2015GL065073.

Broecker, W. S., 1963: Radioisotopes and large-scale oceanic mixing. The Composition of Sea-Water and Comparative and Descriptive Oceanography, M. N. Hill, Ed., The Sea-Ideas and Observations on Progress in the Study of the Seas, Vol. 2, John Wiley and Sons, 88-108.

Crueger, T., E. Roeckner, T. Raddatz, R. Schnur, and P. Wetzel, 2008: Ocean dynamics determine the response of oceanic $\mathrm{CO}_{2}$ uptake to climate change. Climate Dyn., 31, 151-168, doi:10.1007/s00382-007-0342-x.

Cushman-Roisin, B., 1987: Subduction. Dynamics of the Oceanic Surface Mixed Layer: Proc. 'Aha Huliko'a Hawaiian Winter Workshop, Honolulu, HI, University of Hawai'i at Mānoa, 181-196, http://www.soest.hawaii.edu/PubServices/1987pdfs/ Cushman_Roisin.pdf.

Dai, A., and K. E. Trenberth, 2002: Estimates of freshwater discharge from continents: Latitudinal and seasonal variations. 
J. Hydrometeor., 3, 660-687, doi:10.1175/1525-7541(2002)003<0660 EOFDFC $>2.0 . \mathrm{CO} ; 2$

Fine, R. A., K. A. Maillet, K. F. Sullivan, and D. Willey, 2001: Circulation and ventilation flux of the Pacific Ocean. J. Geophys. Res., 106, 22 159-22 178, doi:10.1029/1999JC000184.

Gent, P. R., and J. C. McWilliams, 1990: Isopycnal mixing in ocean circulation models. J. Phys. Oceanogr., 20, 150-155, doi:10.1175/1520-0485(1990)020<0150:IMIOCM > 2.0.CO;2.

Gruber, N., and Coauthors, 2009: Oceanic sources, sinks, and transport of atmospheric $\mathrm{CO}_{2}$. Global Biogeochem. Cycles, 23, GB1005, doi:10.1029/2008GB003349.

Hanawa, K., and L. D. Talley, 2001: Mode waters. Ocean Circulation and Climate, G. Siedler, J. Church, and J. Gould, Eds., International Geophysics Series, Vol. 77, Academic Press, 373-386.

Huang, R. X., and B. Qiu, 1994: Three-dimensional structure of the wind-driven circulation in the subtropical North Pacific. J. Phys. Oceanogr., 24, 1608-1622, doi:10.1175/ 1520-0485(1994)024<1608:TDSOTW >2.0.CO;2.

Ishii, M., and Coauthors, 2009: Spatial variability and decadal trend of the oceanic $\mathrm{CO}_{2}$ in the western equatorial Pacific warm/ fresh water. Deep-Sea Res. II, 56, 591-606, doi:10.1016/ j.dsr2.2009.01.002.

Iudicone, D., K. B. Rodgers, I. Stendardo, O. Aumont, G. Madec, L. Bopp, O. Mangoni, and M. Ribera d'Alcala', 2011: Water masses as a unifying framework for understanding the Southern Ocean carbon cycle. Biogeosciences, 8, 1031-1052, doi:10.5194/bg-8-1031-2011.

— - _ Y. Y. Plancherel, O. Aumont, T. Ito, R. M. Key, G. Madec, and M. Ishii, 2016: The formation of the ocean's anthropogenic carbon reservoir. Sci. Rep., 6, 35473, doi:10.1038/srep35473.

Key, R. M., and Coauthors, 2004: A global carbon climatology: Results from Global Data Analysis Project (GLODAP). Global Biogeochem. Cycles, 18, GB4031, doi:10.1029/2004GB002247.

Kwon, E. Y., and Coauthors, 2014: Global estimate of submarine groundwater discharge based on an observationally constrained radium isotope model. Geophys. Res. Lett., 41, 8438-8444, doi:10.1002/2014GL061574.

Kwon, Y.-O., and S. C. Riser, 2004: North Atlantic Subtropical Mode Water: A history of ocean-atmosphere interactions, 1961-2000. Geophys. Res. Lett., 31, L19307, doi:10.1029/ 2004 GL021116.

Le Quéré, C., T. Takahashi, E. T. Buitenhuis, C. Roedenbeck, and S. C. Sutherland, 2010: Impact of climate change and variability on the global oceanic sink of $\mathrm{CO}_{2}$. Global Biogeochem. Cycles, 24, GB4007, doi:10.1029/2009GB003599.

Levine, N. M., S. C. Doney, I. Lima, R. Wanninkhof, N. R. Bates, and R. A. Feely, 2011: The impact of the North Atlantic Oscillation on the uptake and accumulation of anthropogenic $\mathrm{CO}_{2}$ by North Atlantic Ocean Mode Waters. Global Biogeochem. Cycles, 25, GB3022, doi:10.1029/2010GB003892.

Lévy, M., L. Bopp, P. Karleskind, L. Resplandy, C. Ethe, and F. Pinsard, 2013: Physical pathways for carbon transfers between the surface mixed layer and the ocean interior. Global Biogeochem. Cycles, 27, 1001-1012, doi:10.1002/gbc.20092.

Madec, G., P. Delecluse, M. Imbard, and C. Lévy, 1998: OPA 8.1 ocean general circulation model reference manual. Institut Pierre-Simon Laplace (IPSL) Note du Pole de Modélisation $11,91 \mathrm{pp}$

Matsumoto, K., K. S. Tokos, M. O. Chikamoto, and A. Ridgwell, 2010: Characterizing post-industrial changes in the ocean carbon cycle in an Earth system model. Tellus, 62B, 296-313, doi:10.1111/j.1600-0889.2010.00461.x.
Mikaloff-Fletcher, S. E., and Coauthors, 2006: Inverse estimates of anthropogenic $\mathrm{CO}_{2}$ uptake, transport, and storage by the ocean. Global Biogeochem. Cycles, 20, GB2002, doi:10.1029/ 2005GB002530.

Nakano, H., M. Ishii, K. B. Rodgers, H. Tsujino, and G. Yamanaka, 2015: Anthropogenic $\mathrm{CO}_{2}$ uptake, transport, storage, and dynamical controls in the ocean imposed by the meridional overturning circulation: A modeling study. Global Biogeochem. Cycles, 29, 1706-1724, doi:10.1002/2015GB005128.

Oeschger, H. U., U. Siegenthaler, U. Schotterer, and A. Gugelman, 1975: A box diffusion model to study the carbon dioxide exchange in nature. Tellus, 27, 168-192, doi:10.3402/ tellusa.v27i2.9900.

Oka, E., and Coauthors, 2015: Decadal variability of subtropical mode water subduction and its impact on biogeochemistry. J. Oceanogr., 71, 389-400, doi:10.1007/s10872-015-0300-x.

Qiu, B., and R. X. Huang, 1995: Ventilation of the North Atlantic and North Pacific: Subduction versus obduction. J. Phys. Oceanogr., 25, 2374-2390, doi:10.1175/1520-0485(1995)025<2374: VOTNAA $>2.0 . C O ; 2$

Revelle, R., and H. E. Suess, 1957: Carbon dioxide exchange between atmosphere and ocean and the question of an increase of atmospheric $\mathrm{CO}_{2}$ during the past decades. Tellus, 9, 18-27, doi:10.3402/tellusa.v9i1.9075.

Rodgers, K. B., B. Blanke, G. Madec, O. Aumont, P. Ciais, and J.-C. Dutay, 2003: Extratropical sources of equatorial Pacific upwelling in an OGCM. Geophys. Res. Lett., 30, 1084, doi:10.1029/2002GL016003.

, O. Aumont, G. Madec, C. Menkes, B. Blanke, P. Monfray, J. C. Orr, and D. P. Schrag, 2004: Radiocarbon as a thermocline proxy for the eastern equatorial Pacific. Geophys. Res. Lett., 31, L14314, doi:10.1029/2004GL019764.

Sallée, J.-B., R. J. Matear, S. R. Rintoul, and A. Lenton, 2012: Localized subduction of anthropogenic carbon dioxide in the Southern Hemisphere oceans. Nat. Geosci., 5, 579-584, doi:10.1038/ngeo1523.

Sarmiento, J. L., J. C. Orr, and U. Sigenthaler, 1992: A perturbation simulation of $\mathrm{CO}_{2}$ uptake in an ocean general circulation model. J. Geophys. Res., 97, 3621-3645, doi:10.1029/91JC02849.

Stommel, H., 1979: Determination of water mass properties of water pumped down from the Ekman layer to the geostrophic flow below. Proc. Natl. Acad. Sci. USA, 76, 3051-3055, doi:10.1073/pnas.76.7.3051.

Suga, T., Y. Aoki, H. Saito, and K. Hanawa, 2008: Ventilation of the North Pacific subtropical pycnocline and mode water formation. Prog. Oceanogr., 77, 285-297, doi:10.1016/ j.pocean.2006.12.005.

Takahashi, T., and Coauthors, 2009: Climatological mean and decadal change in surface ocean $\mathrm{pCO}_{2}$, and net sea-air $\mathrm{CO}_{2}$ flux over the global oceans. Deep-Sea Res. II, 56, 554-577, doi:10.1016/j.dsr2.2008.12.009.

Thomas, M. D., A.-M. Tréguier, B. Blanke, J. Deshayes, and A. Voldoire, 2015: A Lagrangian method to isolate the impacts of mixed layer subduction on the meridional overturning circulation in a numerical model. J. Climate, 28, 7503-7517, doi:10.1175/JCLI-D-14-00631.1.

Walin, G., 1982: On the relation between sea-surface heat flow and thermal circulation in the ocean. Tellus, 34, 187-195, doi:10.3402/tellusa.v34i2.10801.

Williams, R. G., V. Roussenov, and M. J. Follows, 2006: Nutrient streams and their induction into the mixed layer. Global Giogeochem. Cycles, 20, GB1016, doi:10.1029/2005GB002586. 